\title{
The Effects of Immune System Modulation on Prion Disease Susceptibility and Pathogenesis
}

\author{
Neil A. Mabbott *๑), Barry M. Bradford $\oplus^{\circ}$, Reiss Pal, Rachel Young and David S. Donaldson \\ The Roslin Institute \& Royal (Dick) School of Veterinary Studies, University of Edinburgh, Easter Bush, \\ Midlothian EH25 9RG, UK; barry.bradford@roslin.ed.ac.uk (B.M.B.); R.Pal@sms.ed.ac.uk (R.P.); \\ rachel.young@roslin.ed.ac.uk (R.Y.); david.donaldson@roslin.ed.ac.uk (D.S.D.) \\ * Correspondence: neil.mabbott@roslin.ed.ac.uk; Tel.: +44-131-651-9100
}

Received: 9 September 2020; Accepted: 29 September 2020; Published: 2 October 2020

\begin{abstract}
Prion diseases are a unique group of infectious chronic neurodegenerative disorders to which there are no cures. Although prion infections do not stimulate adaptive immune responses in infected individuals, the actions of certain immune cell populations can have a significant impact on disease pathogenesis. After infection, the targeting of peripherally-acquired prions to specific immune cells in the secondary lymphoid organs (SLO), such as the lymph nodes and spleen, is essential for the efficient transmission of disease to the brain. Once the prions reach the brain, interactions with other immune cell populations can provide either host protection or accelerate the neurodegeneration. In this review, we provide a detailed account of how factors such as inflammation, ageing and pathogen co-infection can affect prion disease pathogenesis and susceptibility. For example, we discuss how changes to the abundance, function and activation status of specific immune cell populations can affect the transmission of prion diseases by peripheral routes. We also describe how the effects of systemic inflammation on certain glial cell subsets in the brains of infected individuals can accelerate the neurodegeneration. A detailed understanding of the factors that affect prion disease transmission and pathogenesis is essential for the development of novel intervention strategies.
\end{abstract}

Keywords: prions and prion disease; immune system; inflammation; aging; co-infection; susceptibility

\section{Introduction}

Prion diseases, also referred to as transmissible spongiform encephalopathies, are subacute, infectious, neurodegenerative diseases that affect humans and some domestic and free-ranging animal species to which there are no effective treatments. A characteristic feature of the prion diseases is the accumulation of $\mathrm{PrP}^{\mathrm{Sc}}$ (abnormally folded isoforms of the mammalian host's cellular prion protein, $\mathrm{PrP}^{\mathrm{C}}$ ) in affected tissues [1]. The accumulation of $\mathrm{PrP}^{\mathrm{Sc}}$ in the central nervous system (CNS) ultimately leads to the development of spongiform pathology (vacuolation) and neurodegeneration. A unique feature of these diseases when compared to other neurodegenerative disorders is their transmissibility. Prion infectivity co-purifies with $\mathrm{PrP}^{\mathrm{Sc}}$ implying that prion particles are mostly, if not entirely, comprised of infectious proteins [2].

The cellular $\operatorname{PrP}^{\mathrm{C}}$ glycoprotein is encoded by the PRNP gene and is expressed on the surface of most cell types via its glycosylphosphatidylinositol anchor. In the CNS, Prnp is expressed predominantly in neurons, astrocytes and oligodendrocytes when compared to microglia ([3]; https://www.brainrnaseq. org/), and expression of the $\mathrm{PrP}^{\mathrm{C}}$ protein may be important in maintaining myelin homeostasis [4]. Despite this widespread expression, the precise function of $\operatorname{PrP}^{\mathrm{C}}$ remains the subject of much debate. However, transgenic mice in which the Prnp gene is ablated ( $\mathrm{Prnp}^{-/-}$mice) are fertile and appear to be developmentally normal [5,6]. Likewise, Norwegian dairy goats that lack $\operatorname{PrP}^{\mathrm{C}}$ expression due to the presence of an early stop-codon mutation in their PRNP gene are also healthy [7]. In humans, 
several naturally-occurring loss-of-function mutations in PRNP have been identified and appear to be tolerated [8]. Cellular $\mathrm{PrP}^{\mathrm{C}}$ is also expressed in most immune cell lineages and may act as an uptake receptor for certain pathogens [9], or modulate cell phenotype [10]. However, although $\operatorname{PrP}^{\mathrm{C}}$ is expressed highly in key cell populations within the B cell follicles of the secondary lymphoid organs (SLO), $\operatorname{PrP}^{\mathrm{C}}$ deficiency has little impact on the induction of antigen-specific antibody responses [11].

Expression of $\mathrm{PrP}^{\mathrm{C}}$ is, however, essential for prion replication in host cells [5]. During prion disease, important post-translational changes occur to the structure of the $\operatorname{PrP}^{\mathrm{C}}$ molecule that lead to the formation of $\operatorname{PrP}^{S c}$ [12]. These changes affect the physicochemical and biologic characteristics of the $\mathrm{PrP}$ molecule, such that prion disease-specific $\mathrm{PrP}^{\mathrm{Sc}}$ is relatively resistant to proteinase digestion (when compared to $\mathrm{PrP}^{\mathrm{C}}$ ), can form insoluble aggregates and can induce the autocatalytic conversion of further copies of $\mathrm{PrPC}^{\mathrm{C}}$ into $\mathrm{PrP}^{\mathrm{Sc}}$.

To date, a variety of different types of prion diseases have been described. The spontaneous prion diseases, such as sporadic Creutzfeldt-Jakob disease (sCJD) in humans, appear to have an unknown aetiology. This disease typically affects elderly individuals ( $>60$ years old), with a worldwide incidence of approximately 1 case/million population/year. Disease is considered to arise through the spontaneous generation and accumulation of prions in the brains of affected individuals. Some prion diseases can be inherited, and are linked to specific mutations in the PRNP gene that appear to predispose the individuals that carry these mutations to prion diseases such as Gerstmann-Sträussler-Scheinker disease (GSS) and fatal familial insomnia [13]. Prion diseases can also be acquired and transmitted between individuals, including natural sheep scrapie, chronic wasting disease in cervid species and bovine spongiform encephalopathy (BSE) in cattle. The demonstration that consumption of BSE-contaminated food during the UK BSE epidemic was responsible for the occurrence of variant Creutzfeldt-Jakob disease (vCJD) in younger people (median age of onset 29 years old) $[14,15]$ showed how some prion diseases could have zoonotic potential with important consequences for human health. Although SCJD is not considered to be an acquired disease, accidental iatrogenic transmissions have been recorded: for example after the transplantation of tissues (dura mater grafts) or tissue products (pituitary-derived human growth hormones) derived from the brains of SCJD-infected donors, and the use of contaminated surgical instruments [13]. Examples of accidental iatrogenic vCJD transmissions have similarly been reported due to the transfusion of blood or blood products from vCJD-infected donors (for a detailed account of the transmission of prions between species, see [16]).

An understanding of the factors that can affect prion disease transmission and pathogenesis is important for managing disease risk and the development of effective treatments. Early studies in mice revealed that some prion strains accumulated to high levels within days in SLO after peripheral injection, and before the prions had spread to the brain [17]. Subsequent studies showed that specific antibody responses to agents responsible for prion diseases were not induced, despite the high burdens of prions within the SLO in infected mice [18-20]. With hindsight, we now know that this lack of an anti-prion ( $\mathrm{PrP}^{\mathrm{Sc}}$-specific) antibody response is most likely due the tolerance of the immune system to cellular $\mathrm{PrP}^{\mathrm{C}}$. However, although prion infections do not induce strong prion-specific immunity in the majority of infected individuals, the interactions between the prions and certain immune cell populations are essential for disease development, whereas interactions with some immune cells can provide host protection. For example, the study by Eklund and colleagues was the first to suggest that cells within the SLO may actually be sites of prion replication [17]. Soon afterwards, other studies revealed that this peripheral phase of prion replication in SLO such as the spleen was important for the efficient transmission of disease to the CNS [21]. These studies were soon accompanied by others that showed how modulation of the immune system around the time of peripheral exposure could have a profound influence prion disease pathogenesis [22-25].

Here we discuss how the peripherally-acquired prions exploit certain tissues and immune cells to establish infection. We focus on the peripherally-acquired prion diseases such as natural sheep scrapie, chronic wasting disease in cervid species and BSE in cattle, as these are considered to be transmitted by the oral route through the ingestion of food or pasture contaminated with prions. The consumption of 
food contaminated with BSE prions was similarly the original cause of VCJD in humans (for an in-depth review on transmission routes, see [16]). We also provide a detailed account of how inflammation, ageing and pathogen co-infection can have a significant impact on prion disease pathogenesis and susceptibility by causing changes to the abundance, function and activation status of specific immune cell populations.

\section{Splenectomy before Intraperitoneal Prion Infection Extends Survival Times}

At the time of writing, five decades have passed since it was originally revealed that the actions of the host immune system could modulate prion disease pathogenesis and susceptibility. The immune system is essential in providing protection against infections with many conventional pathogens. However, quite the opposite has been shown to occur in animals infected with prions by peripheral routes of exposure such as the peritoneal cavity, by subcutaneous injection or via the gastrointestinal tract. Experiments revealed that high levels of scrapie prions accumulated in the spleens of mice within days after peripheral injection and this occurred before the detection of prions in CNS tissues [17,26] (Figure 1A). The impact that this early, non-CNS, prion accumulation had on disease pathogenesis was not known at the time and investigated in a subsequent set of seminal experiments. In that study, the spleens were removed from mice (splenectomy), and once healed, they were subsequently infected with prions [21]. The spleen contains many specialized immune cell populations that are localized in specific niches and these play an important role in providing protection against systemic pathogens, and the removal of their antigens and toxins from the blood-stream [27]. Contrary to these properties, splenectomy prior to, or up to 60 days after an intraperitoneal (IP) prion infection, significantly delayed the onset of the clinical signs of disease [21] (Figure 1B). This revealed that rather than providing host protection, the spleen and other elements of the immune system may conversely play an important role in the establishment of some prion infections. Additional experiments revealed that splenectomy had no effect on disease pathogenesis when the prions were injected with prions directly into the CNS by intracerebral (IC) injection [21]. This finding indicated that the spleen was not simply generating adaptive immune responses that directly caused neuronal damage in the brain. Many follow-up studies have since reinforced this conclusion, and shown that prion disease pathogenesis after IC injection is unaltered in the absence of T cells and B cells [28-30].

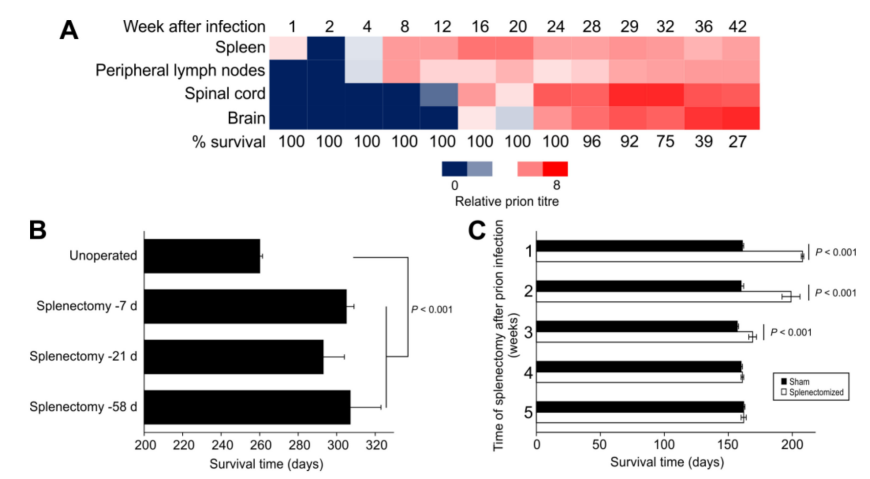

Figure 1. The spleen is an important early site of prion replication and neuroinvasion after peripheral infection. (A) In 1967, Eklund et al. [17] showed that high levels of RML scrapie prions accumulated in the spleens of Swiss mice within days after subcutaneous injection, and this occurred before the prions were detected in the spinal cord and brain. Heatmap shows negative log 10 of dilution of tissue suspension that contained $1 \mathrm{LD}_{50} / 30 \mu \mathrm{L}$ when injected intracerebrally into recipient mice. (B) In 1970, Fraser and Dickinson [21] showed that splenectomy before IP injection of C57BL/Dk mice with ME7 scrapie prions significantly extended the survival times. Bars, mean \pm SEM; $n=3-22$ mice/group. (C) In 1989, Kimberlin and Walker [31] concluded that splenectomy did not extend survival times once infection was established in the spinal cord. In their experiment Compton White mice were IP injected with 139A scrapie prions and the splenectomy performed at the times indicated after prion injection. Bars, mean \pm SEM; $n=4-9$ mice/group. 
Analysis of the build up or accumulation of prions in various tissues of mice after peripheral routes of exposure revealed that SLO such as the spleen were amongst the first to be targeted by prions [17]. Soon afterwards, the infection was also detectable in the spinal cord and at later stages in the brain (Figure 1A). Chronological analyses of natural host species, including sheep, cattle and cervids, infected with prions by peripheral routes of exposure have also demonstrated similar disease kinetics [32-35]. Importantly, these studies raised the suggestion that the initial accumulation of the prions in SLO such as the spleen was required for them to efficiently infect the nervous system, a process that was termed neuroinvasion. Indeed, comparison of the effects of splenectomy and disease kinetics revealed that the pathogenesis became independent of the spleen once infection was established in the spinal cord [31] (Figure 1C). Contemporary studies have since demonstrated the requirement for early prion accumulation in the local draining lymph nodes after prion infection via skin lesions [36], and the Peyer's patches in the small intestine after oral exposure [37-40]. This requirement for initial targeting of certain prion strains to the SLO to establish infection has been termed lymphotropism. It is important, however, to mention that examples of non-lymphotrophic prion agent strains exist. Infection with non-lymphotrophic prion strains such as SCJD in humans do not appear to involve significant involvement of the SLO [16]. While it is plausible that SCJD may arise due to the spontaneous misfolding of prions in the brains of affected individuals, accidental iatrogenic transmissions of SCJD (iatrogenic CJD) in humans have occured between individuals via peripheral routes [16]. Since BSE in infection in cattle also appears to have little SLO involvement [16], this suggests that BSE prions have increased tropism for the bovine nervous system. This may potentially negate the need for BSE prions to be processed and amplified within bovine SLO to establish infection of the nervous system.

The findings from the above studies raised the suggestion that treatments that prevented the early build up of certain prion lymphotrophic strains within SLO might help reduce disease transmission, for example by delaying or even preventing the spread of prions to the CNS. Those original experiments reported in the late 1960s and early 1970s, undertaken before prions were proposed and identified, stimulated an exciting and active period of research as tools such as transgenic and "knock-out" mice became available. These studies have identified many of the cellular components that the prions exploit to accumulate in SLO, and shown how modulation of the function or activation status of the cells in these tissues can affect disease pathogenesis and susceptibility. Over the years there have been many useful reviews that have described how prions exploit specific cell populations within the SLO to establish host infection [16,41-45]. Consequently, only the main studies are briefly described in this review, and we refer readers to the above publications if they would like to read further details. We instead focus on how immune stimulation, immunosuppression, pathogen co-infection and changes to the abundance, function or activation status of key immune cell populations can affect prion disease pathogenesis and susceptibility.

\section{Immune Stimulation Accelerates, Immunosuppression Delays}

The suggestion that the activation status of the host immune system could modulate the kinetics of a peripherally-acquired prion disease is not a recent concept and was first recognized in the 1970s. However, once again, the effect of immune stimulation and immunosuppression on prion disease pathogenesis where contrary to the effect such treatments might have been following infection with other pathogenic microorganisms. These studies showed that treatment with immune stimulants such as the mitogen phytohaemagluttinin (PHA) [22] or BCG extract [23] could each accelerate the rate of onset of prion disease after infection by the IP route, and in the case of PHA significantly increase disease susceptibility [22]. In hamsters, the effects of intraperitoneal adenovirus infection on macrophages were similarly associated with a $20 \%$ reduction in disease duration when compared with animals infected only with prions [46]. Conversely, treatment with the anti-inflammatory steroid prednisone acetate extended survival times and reduced disease susceptibility [47]. Other anti-inflammatory treatments such as arachis oil or dextran sulphate 500 (single IP injection of $250 \mu \mathrm{g}$ ) similarly delayed 
disease pathogenesis [24,25]. One study proposed that the reduced susceptibility of mice to IP scrapie prion infection given daily injections with the immune stimulatory $\mathrm{CpG}$ oligodeoxynucleotides (for 4 or 20 days after infection) was mediated through such actions on mononuclear phagocytes [48]. However, an independent follow-up study revealed that the repeated CpG treatment used in the above study [48] caused gross disturbances to the microarchitecture of the SLO, including ablation of the FDC networks [49], the key sites of prion replication in these tissues.

At the time that many of the above studies were undertaken, little was understood of the underlying mechanisms responsible for the effects these treatments had on prion disease. However, these treatments were only effective when administered within a short time window immediately before or after the mice were injected with prions by the IP route. This implied that these treatments were modulating the abundance or activity of cells that may aid the propagation of the prions from the peritoneal cavity to their initial replication sites in the spleen. Alternatively, they could also affect the activity of phagocytic cells that could sequester and destroy the prions in the vicinity of the injection site or as they arrive in the spleen (see Section 6.3.).

\section{Major Histocompatibility Complex (MHC)}

The MHC class I and MHC class II molecules encoded by genes in the MHC complex enable short peptides from antigens, either endogenous or pathogen derived, to be displayed on the surfaces of host cells. MHC class I is expressed on all nucleated cells, whereas MHC class II is predominantly expressed on antigen presenting cells. T cells have receptors that specifically recognize these antigen-derived peptides in association with the MHC molecule, the consequence of which is to mount an antigen-specific immune response. Variants in MHC gene allele expression and certain polymorphisms can affect the efficacy of the immune response and are important in the susceptibility to many infectious diseases [50].

Patients with vCJD were reported to have a significantly reduced frequency of the MHC class II type HLA-DQ7 compared to SCJD patients and controls [51]. This raised the suggestion that certain MHC class II molecules may have a direct role in vCJD pathogenesis, or alternatively, that MHC class II type HLA-DQ7 may be more effective at initiating a protective immune response following vCJD infection. However, an independent follow-up study that analysed the same and additional vCJD patients was unable to find any significant association between vCJD patients and MHC type [52]. Genetic deficiency in MHC class I and MHC class II in mice also had no effect on disease duration and susceptibility after IC injection with the Chandler mouse scrapie strain [53]. Together, these data indicate that variants in MHC type do not influence prion disease susceptibility.

\section{Prions First Replicate upon Follicular Dendritic Cells in SLO}

Mouse studies have shown that within days of peripheral infection, certain lymphotrophic prions accumulate upon the surface of stromal follicular dendritic cells (FDC) within the B cell follicles of SLO [54]. In the absence of FDC, the accumulation of prions in the spleen is blocked and disease susceptibility reduced $[29,30,55,56]$ (Figure 2). These and many other subsequent studies have illustrated how the early targeting of certain prion strains to FDC is essential for efficient establishment of infection, and highlight a critical rate-limiting step in the neuroinvasion process. Indeed, data also suggest that the initial targeting of lymphotrophic prion strains to FDC is important to enable their adaptation to the host environment and to amplify them above the threshold required for neuroinvasion [57-60]. 

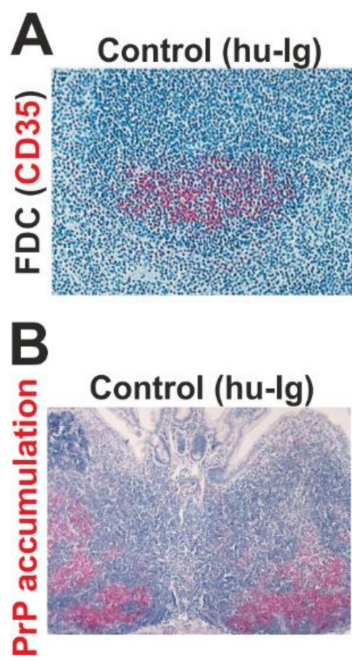
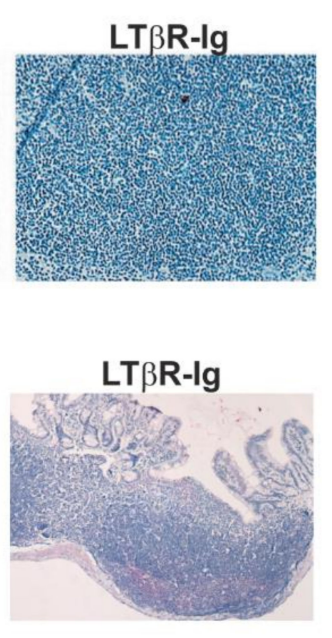

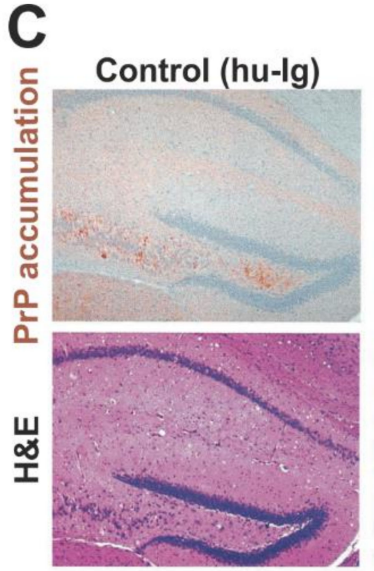

Clinical disease at $\sim 340 \mathrm{~d}$

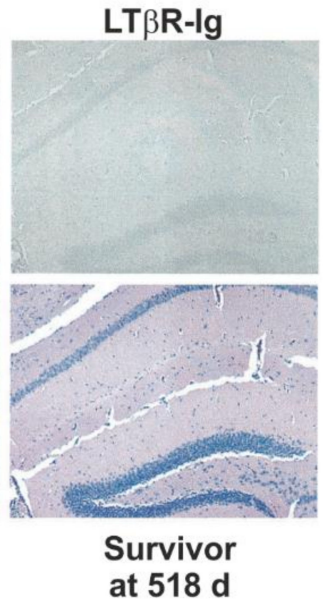

Figure 2. Oral prion disease pathogenesis is impeded in the transient absence of follicular dendritic cells (FDC) at the time of infection [61]. (A) Immunohistochemical (IHC) analysis shows that the treatment of mice with a soluble lymphotoxin $\beta$ receptor (LT $\beta R-I g)$ transiently ablates FDC (CD35+ cells, red) in secondary lymphoid tissues. (B) Prion accumulation (here shown as disease-specific PrP accumulation by IHC, red) is blocked in Peyer's patches in the absence of FDC at the time of oral prion infection. (C) Oral prion disease susceptibility is blocked in the absence of FDC at the time of oral prion infection. Upper images show IHC detection of disease-specific PrP (brown) and lower H\&E-stained panels show presence of prion disease-specific vacuolation (spongiform pathology) in the brains of clinically-affected control mice. All sections counterstained with haematoxylin (blue). Adapted with permission from the American Society for Microbiology from [61] (J. Virol. 2003; 77:6845-6854. https://doi.org/10.1128/JVI.77. 12.6845-6854.2003).

\subsection{FDC Trap Prions in a Complement-Dependent Manner}

FDC express high levels of complement receptors 1 and 2 (CR1/CD35 and CR2/CD21) and use them to trap and retain intact antigens on their surface within antibody- and/or complement component-opsonized immune complexes. The long-term retention of antigens on FDC enables B cells to generate effective antigen-specific antibody responses [62-64]. FDC similarly trap and retain prions on their surfaces as complement-bound complexes [65-71].

The transient ablation of FDC or depletion of opsonising complement components such as C3 can each impede prion accumulation in the spleen, delay neuroinvasion, and in some instances these defects can reduce disease susceptibility [61,65,72-75]. This suggests that factors affecting the size and abundance of FDC in SLO such as active immunisation [76] and LPS exposure [77], or their ability to trap and retain immune complexes, could have a significant impact on susceptibility to peripherally-acquired prion infections.

\subsection{Ageing Affects FDC and their Ability to Trap Prions}

As we age, our immune systems become less effective (termed immunosenescence) and the changes this causes correlate with the reduced efficacy of vaccines in elderly individuals, an increased susceptibility to infections, as well as the increased incidence of cancer and autoimmunity. However, just as immunosuppression can impede prion pathogenesis (Section 3), immunosenescence may have a similar effect. Several studies have shown that aged mice ( $\geq 18$ months old) have reduced susceptibility to peripheral prion infections administered via the IP, intravenous and oral routes $[59,78,79]$. This reduced susceptibility in the aged mice coincides with disturbances to FDC networks that hinder their ability to trap and retain complement-opsonized immune complexes [78,80-82]. The effects of immunosenescence on FDC function may create a significant barrier to susceptibility to peripheral prion infections, especially for cross-species transmissions [59], and may help explain why the majority of clinical vCJD 
cases in the UK have been identified in young individuals, with relatively few in the elderly [83]. A similar correlation between age, lymphoid follicle size and scrapie susceptibility has also been reported in sheep [84].

\section{3. $\operatorname{Pr} P^{C}$ Abundance on FDC Affects Disease Susceptibility}

Expression of cellular $\operatorname{PrP}^{\mathrm{C}}$ is essential for prion replication, and changes to the expression level on host cells can affect disease kinetics [85]. FDC express high levels of $\operatorname{PrP}^{\mathrm{C}}$ and is essential for the replication of prions on their surface $[56,57,86]$. As expected, changes to the magnitude of $\operatorname{PrP} C$ expression in FDC can affect prion disease pathogenesis. Indeed, when $\operatorname{PrP}^{\mathrm{C}}$ expression is ablated only in FDC this blocks both prion replication in the spleen and neuroinvasion [57]. Spleens of neonatal mice [87] and aged mice [78] lack $\mathrm{PrP}^{\mathrm{C}}$-expressing FDC, and this similarly impedes prion replication. Conversely, passive immunisation [88] or active immunisation [76] can each increase FDC abundance, network size and $\mathrm{PrP}^{\mathrm{C}}$ expression. Furthermore, the increased abundance and size of the FDC in the spleens of mice after active immunisation coincide with increased susceptibility to IP prion infection [76]. The magnitude of the $\mathrm{PrP}^{\mathrm{C}}$ expressed on FDC may also influence the tropism of prions to SLO [60], and affect the ability of those prions to transmit to other host species [58].

\subsection{The Distance between FDC and Nerves Is Rate Limiting}

The SLO are highly innervated with neurons from both sympathetic and parasympathetic components of the peripheral nervous system. When the prions on the FDC surface are amplified to above the magnitude required to achieve neuroinvasion, they subsequently infect local sympathetic and parasympathetic neurons in the SLO and spread along them to the CNS $[54,89,90]$. Although the mechanism by which the prions are propagated between FDC and the peripheral nervous system is undetermined, the relative positioning between these cells and the density of sympathetic innervation in the SLO and both directly affect the rate of neuroinvasion $[89,91]$. This highlights another factor that could affect an individual's risk of susceptibility to a peripherally-acquired prion infection.

\section{Propagation of Prions to FDC in Peyer's Patches}

Many natural prion infections are transmitted by the oral route, such as following the ingestion of food or pasture contaminated with prions. After oral exposure, the initial replication of prions upon the FDC in the gut-associated lymphoid tissues (GALT) of the small intestine such as the Peyer's patches and mature (FDC-containing) isolated lymphoid follicle is essential for efficient neuroinvasion [37-40]. A series of studies in mice has revealed how the prions exploit specific innate immune cell populations to establish infection upon FDC in the GALT. Furthermore, factors that modify the abundance or function of these cells can significantly alter susceptibility to orally-acquired prion infections.

\subsection{Cells are the Gate Keepers of Prions in the Intestine}

A single layer of epithelial cells (enterocytes) connected by tight junctions helps to protect the body from the lumenal contents of the intestine. However, the specialized epithelial layer that covers the GALT, the follicle-associated epithelium (FAE), contains a unique population of phagocytic enterocytes known as $\mathrm{M}$ cells (reviewed in [92]). Through a process called transcytosis, these cells constitutively sample the lumenal contents of the intestine and transfer particles and pathogens across the FAE to the leukocytes and lymphocytes beneath it in their basolateral pocket structures. The transcytosis of particulate antigens by $\mathrm{M}$ cells is an important initial step in the induction of antigen-specific mucosal immune responses to certain pathogens and their toxins, and may also help maintain homeostasis in the commensal gut microbiome [92,93].

The ability of M cells to transcytose particles from the gut lumen into the GALT has been exploited by some orally-acquired pathogens as an efficient route of infection into host tissues. Prions also appear to exploit these characteristics. Within an hour after oral infection prions can be detected within 
M cells in the FAE of small intestinal Peyer's patches, and the absence of these cells at the time of oral exposure blocks disease transmission [54,94-96] (Figure 3A,B). Thus, M cells in the FAE overlying the GALT appear to be the initial gate keepers of oral prion infections in the small intestine.

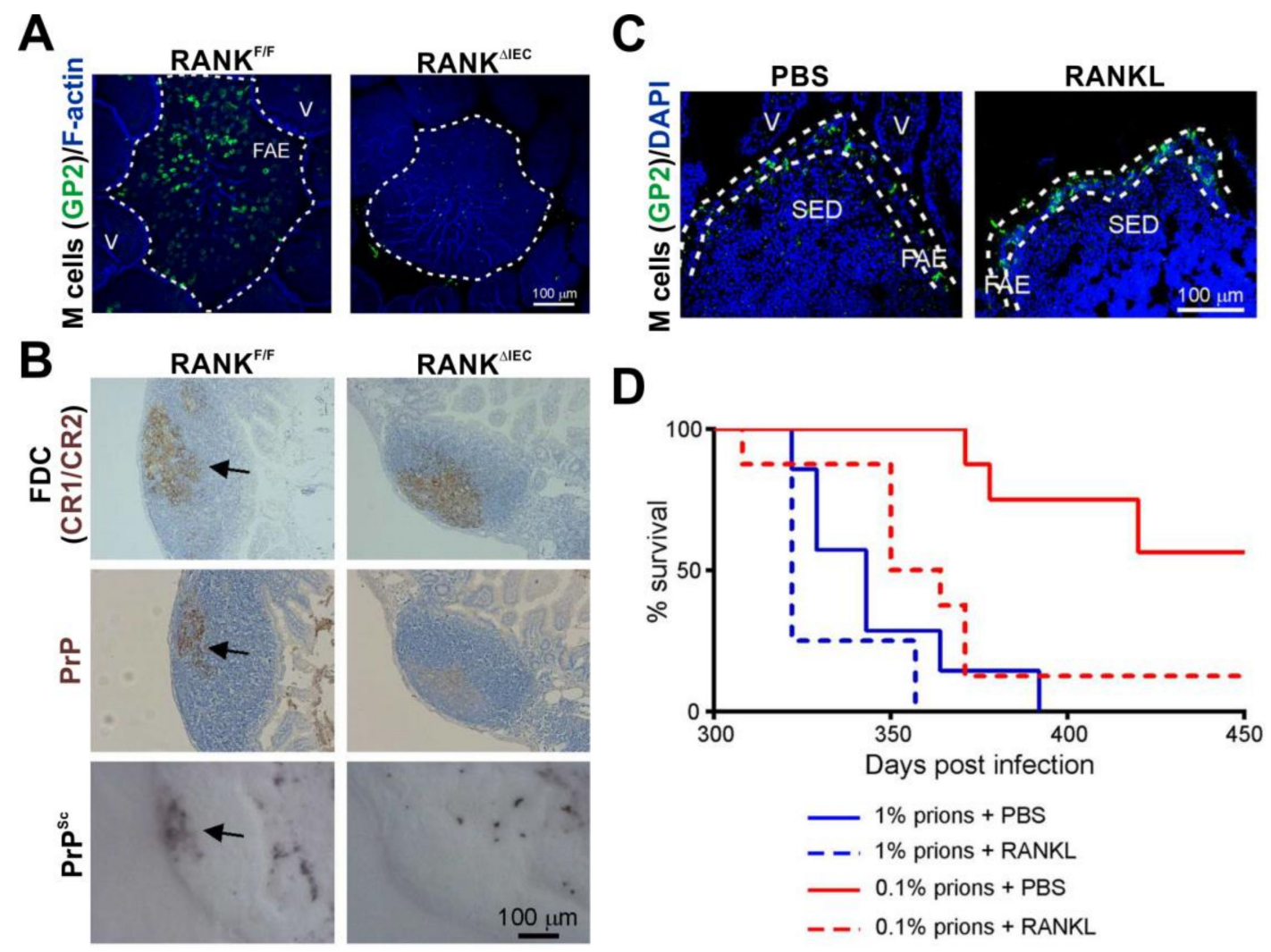

Figure 3. The density of M cells in the epithelia covering the Peyer's patches directly influences oral prion disease susceptibility [96]. (A) Immunofluorescence microscopy shows that RANK ${ }^{\Delta \text { IEC }}$ mice specifically lack M cells (GP2+ cells, green) in the follicle-associated epithelia (FAE) of their Peyer's patches. F-actin, blue. V, villus. (B) In the absence of M cells the accumulation of prions (PrPSc, black and PrP, brown, arrows) upon FDC (CR1/CR2+ cells, brown) in the Peyer's patches of RANK ${ }^{\Delta I E C}$ mice is blocked. (C) Immunofluorescence microscopy shows that systemic treatment of C57BL/6J mice with the cytokine RANKL increases the abundance of M cells (GP2+ cells, green) in the FAE. DAPI, cell nuclei, blue. SED, subepithelial dome. (D) RANKL treatment significantly increases susceptibility to oral prion infection by $\sim 10 X$. PBS $/ 1 \%$ vs. RANKL/1\%, $p=0.120 ;$ PBS $/ 0.1 \%$ vs. RANKL $/ 0.1 \%, p<0.0078$; PBS $/ 1 \%$ vs. RANKL $/ 0.1 \%, p=0.205$; Log-rank [Mantel-Cox] test). Adapted from [96] under the terms of the Creative Commons Attribution Licence (CC-BY-4.0; https://creativecommons.org/licenses/by/4.0/).

Certain pathogens, such as the bacterium Salmonella enterica serovar Typhimurium can specifically manipulate the characteristics of the enterocytes lining the intestine to aid infection, for example by inducing the rapid trans-differentiation of the enterocytes into $\mathrm{M}$ cells [97]. Treatments such as bacterial flagellin or exposure to a young commensal microbiota can similarly enhance $\mathrm{M}$ cell density in the Peyer's patches of aged mice [98]. These examples raised the hypothesis that factors that modified the density of $\mathrm{M}$ cells in the gut epithelium might also influence oral prion disease pathogenesis. To test this hypothesis, mice were treated with the cytokine RANKL to increase the differentiation and abundance $M$ cells throughout their intestines [99] (Figure 3C). This study showed that the RANKL-mediated increase in the abundance of M cells in small intestinal Peyer's patches significantly increased susceptibility to oral prion infection by approximately 10 times [96] (Figure 3D).

$\mathrm{M}$ cells express high levels of the cellular $\operatorname{PrP}^{\mathrm{C}}$ on their apical surfaces [100], and this can be used as an uptake receptor for certain pathogenic microorganisms such as Brucella abortus [9]. 
Although pathogen infections and inflammation may enhance $\operatorname{PrP}^{\mathrm{C}}$ expression in the intestine [101], ablation of $\operatorname{PrP}^{\mathrm{C}}$ throughout the gut epithelium did not affect oral prion disease pathogenesis [102]. Changes to the expression level of $\mathrm{PrP}^{\mathrm{C}}$ in $\mathrm{M}$ cells are therefore unlikely to affect susceptibility to oral prion infections.

The density of M cells in the Peyer's patches of aged mice is substantially reduced when compared to young mice [98]. Since oral prion disease is blocked in mice in the absence of M cells [95], the lack of these cells in aged mice most likely contributes to their reduced susceptibility to oral prion infection [78]. However, the age-related decline in $\mathrm{M}$ cells could be reversed with young microbiota or administration of certain bacterial ligands [98], suggesting that the reduced susceptibility to oral prion infection in aged animals could be reversed under the right conditions.

Together, these studies show how the modulation of M cell density by factors such as ageing, co-infection with certain gastrointestinal pathogens, inflammation or exposure to microbial stimuli [97,98,103-105] may be important risk factors that can increase or reduce oral prion disease susceptibility. For example, if immunosenescence is also associated with a reduced $\mathrm{M}$ cell density in elderly humans, this may contribute to their much lower incidence of vCJD cases caused by dietary exposure to BSE prions.

\subsection{Conventional DC Shuttle Prions to FDC}

The mononuclear phagocytes (MNP) arise from hematopoietic precursor cells in the bone marrow and are a heterogeneous population of monocytes, conventional dendritic cells (cDC), and tissue macrophages. The $\mathrm{CDC}$ are an entirely distinct lineage from the stromal derived FDC [106] and are strategically located throughout the body to sample the local environment for pathogens and their antigens. After antigen uptake, these cells typically undergo a degree of maturation and migrate toward the draining lymphoid tissue to initiate a specific immune response. Some cDC populations can retain antigens in their native states and transfer them intact to naïve B cells in order to initiate a specific antibody response [107]. The migratory characteristics of cDC are exploited by prions to ensure their efficient transport from the site of exposure to the draining SLO [108-111]. Mouse cDC and other MNP in the intestine express CD11c (integrin alpha X) highly [112]. In the transient absence of CD11c+ MNP at the time of oral exposure, the early accumulation of prions within Peyer's patches is blocked and disease susceptibility reduced $[108,109]$. When the ability of CD11c+ MNP to migrate into B cell follicles was blocked, this similarly impeded oral prion disease [111].

These studies suggest that prions exploit the migratory characteristics of certain CD11c+ MNP populations such as the $\mathrm{CDC}$ to ensure their efficient delivery to FDC in Peyer's patches. Many distinct MNP populations have been identified in Peyer's patches, and these have been shown to occupy specific anatomical niches $[113,114]$. The $\mathrm{CD} 8 \alpha+\mathrm{CDC}$, for example, are localized within the interfollicular regions of the Peyer's patches [114]. However, factors that specifically affect these cells are unlikely to have significant impact, as the specific deficiency or dysfunction of CD8+CD11c+MNP has no effect on prion disease susceptibility $[115,116]$.

\subsection{Macrophages Can Destroy Prions}

The region of the Peyer's patches beneath the M cell-containing FAE is known as the subepithelial dome (SED), and contains an abundant and mixed population of CDC and macrophages. Prions can be detected within the macrophages in the SED within a few hours after oral infection $[54,94,117]$. Tissue macrophages play important roles in host protection against many infectious diseases by phagocytosing and destroying pathogens. In the early 1980s, data from in vitro studies indicated that peritoneal macrophages could similarly phagocytose and degrade scrapie prions, implying a host-protective role in infected animals $[118,119]$. Consistent with this, the depletion of these cells around the time of oral exposure enhances the accumulation of prions within the Peyer's patches [120,121].

The ability of tissue macrophages to phagocytose and destroy prions raises the possibility that factors or treatments that stimulate this activity could help reduce oral prion disease transmission. However, macrophages can also provide important homeostatic support to certain cell populations in 
the intestine such as M cells and enteric nerves [122-124]. Impairment of this macrophage-derived support, for example as a consequence of pathogen co-infection or inflammation in the intestine, could indirectly affect $\mathrm{M}$ cell function or gut motility and transit time $[125,126]$. Thus, changes to these homeostatic roles in intestinal macrophages could have a significant impact on the $\mathrm{M}$ cell-mediated uptake of prions into Peyer's patches, or affect their ability to infect enteric nerves.

\section{Chronic Inflammation Can Facilitate Prion Targeting in Non-SLO Tissues}

Chronic inflammation in tissues can induce the formation of granulomas within them. Under some circumstances, these granulomas can contain ectopic germinal centres with networks of $\mathrm{PrP}^{\mathrm{C}}$-expressing FDC. Studies in mice have shown that the development of granulomas in the kidney, as a consequence of nephritis, can facilitate the replication of prions in these tissues in prion-infected mice and the excretion of infectious prions in urine $[127,128]$. When induced in the mammary glands of scrapie-affected sheep, for example in response to mastitis, these can similarly act as novel sites of prion replication and transmit prions to suckling lambs via milk [129-131]. Lymphotrophic prions can accumulate in subcutaneous soft tissue granulomas in association with an inflammation-dependent $\mathrm{PrP}^{\mathrm{C}}$-expressing stromal cell population [132], although a subsequent study has suggested a role for a FDC-like cell population [133]. However, not all forms of tissue granulomas appear to be capable of supporting prion accumulation in infected individuals. Granulomas can form in the intestine, for example in the submucosa around the invading larvae of helminth pathogens such as Heligmosomoides polygyrus. These granulomas contain abundant populations of MNP, but due to the absence of FDC or other $\mathrm{PrP}^{\mathrm{C}}$-expressing stromal cells they do not contain $\mathrm{PrP}^{\mathrm{Sc}}$ deposits in mice orally co-infected with prions [134].

\section{Pathogen Co-Infections Can Affect Oral Prion Disease}

\subsection{Gastrointestinal Helminths}

Mammals are often exposed to and infected with gastrointestinal helminth pathogens in their natural environments. Trichuris muris and H. polygyrus are natural helminth pathogens of mice, and have been used to study the effects of gastrointestinal helminth infections on oral prion disease pathogenesis. These helminth pathogens affect different niches in the intestine. H. polygyrus infection, for example, is restricted to the duodenum of the small intestine and causes pathology to the mucosa within it. Co-infection of mice with $H$. polygyrus around the time of oral prion exposure reduced the early accumulation of prions upon FDC in the Peyer's patches and extended disease duration $[134,135]$ (Figure 4A). The delayed prion disease pathogenesis in the mice co-infected with $H$. polygyrus was associated with an altered distribution of CD11c+ MNP in their Peyer's patches with a specific increase in abundance in the B cell mantle region (Figure 4B). This implied that the altered distribution of the cDC in the Peyer's patches of the co-infected mice may have impeded the ability of these cells to efficiently propagate the prions to the FDC within the B cell follicles [134]. 
A
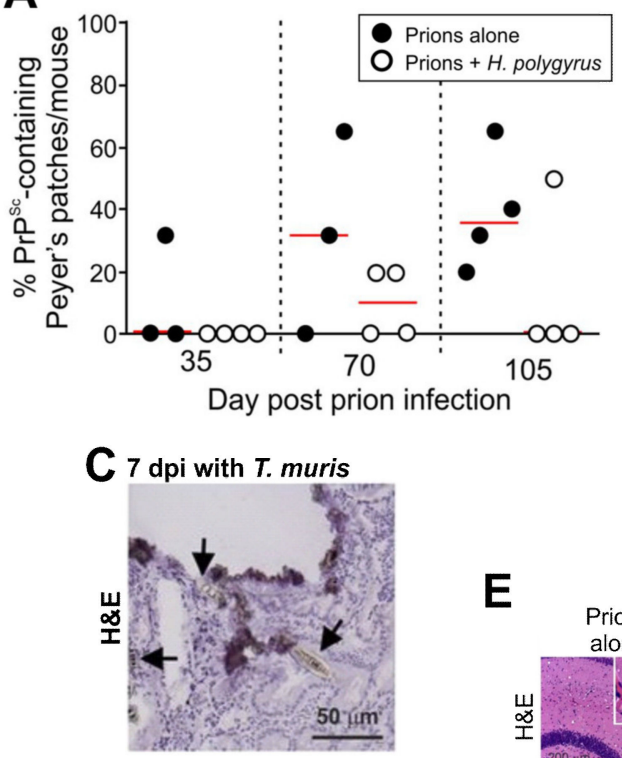

D
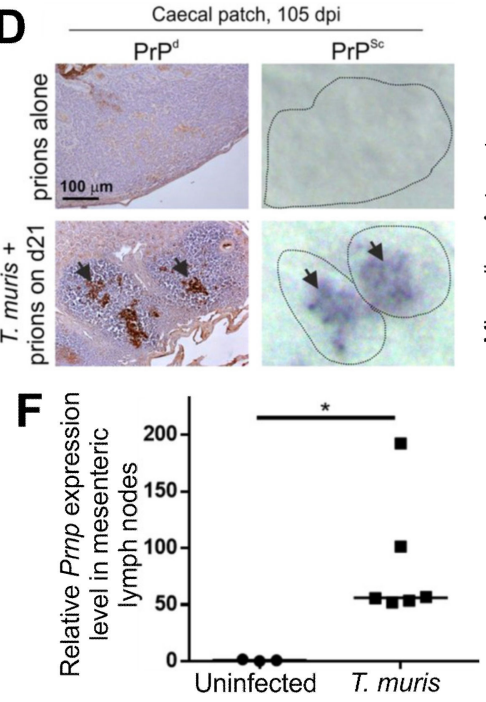

E
B
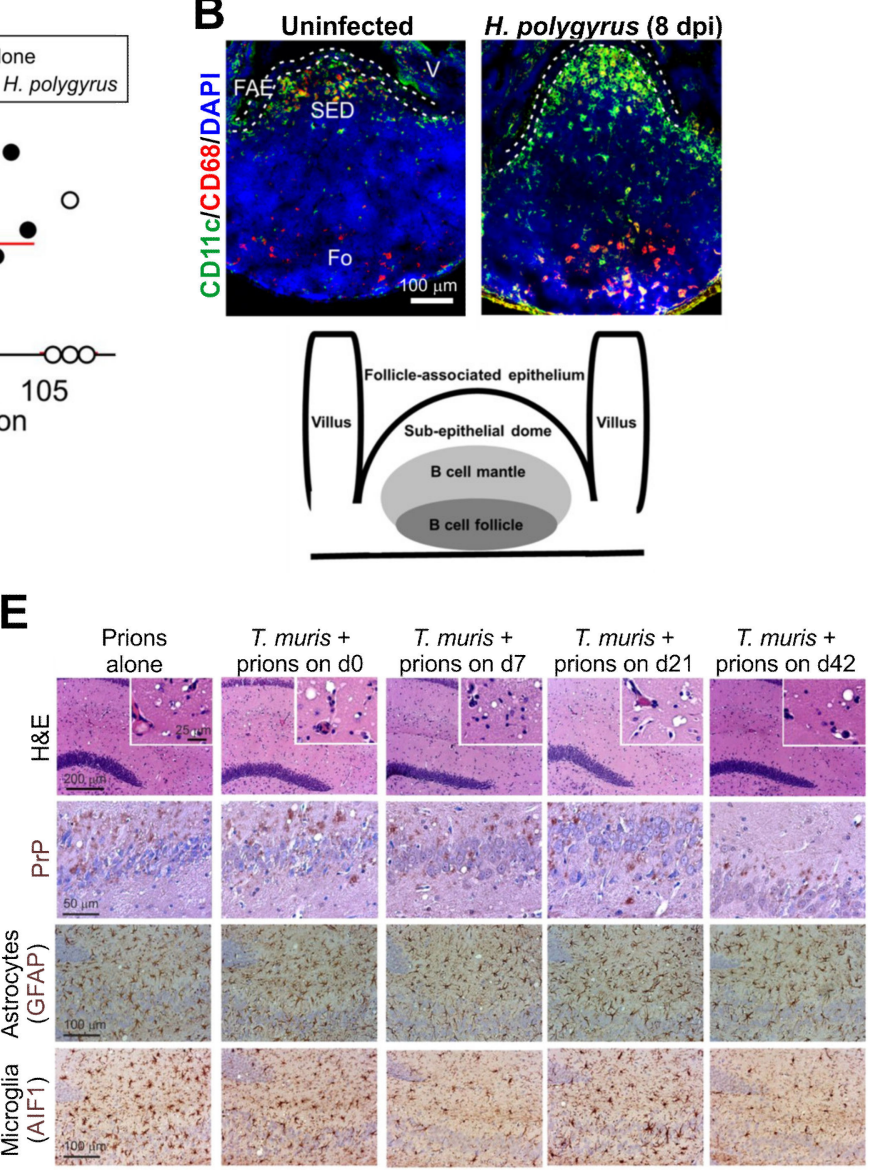

Figure 4. Effect of co-infections with gastrointestinal helminths on oral prion disease pathogenesis in.mice. Panels A and B illustrate the effects of co-infection with Heligmosomoides polygyrus in the small intestine [134]. C57BL/6J mice were first orally-infected with $H$. polygyrus. L3 larvae and orally infected with ME7 scrapie prions 8 days later. (A) The frequency of $\mathrm{PrPS}^{\mathrm{Sc}}$-containing Peyer's patches was lower in mice co-infected with $H$. polygyrus. (B) Immunofluorescent analysis showed that the distribution of $\mathrm{CD} 11 \mathrm{c}+$ mononuclear phagocytes (green) was disturbed in the Peyer's patches on $\mathrm{d} 8$ after H. polygyrus infection. FAE, follicle-associated epithelium; SED, subepithelial dome; Fo, follicle; V, villus; dpi, days post-infection. Cartoon shows the anatomical boundaries in the Peyer's patch. Panels C-E illustrate the effects of co-infection with Trichuris muris in the large intestine [134]. C57BL/6J mice were first orally-infected T. muris infective eggs and orally infected with ME7 scrapie prions and the days indicated after the helminth infection. (C) Arrows show the close association of T. muris with the caecal epithelium and lamina propria and the damage caused to the epithelium. (D) In mice infected with prions alone PrPSc was undetectable in the caecal patches at $105 \mathrm{dpi}$. However, high levels of $\mathrm{PrP}^{\mathrm{Sc}}$ were detected in the caecal patches of the mice co-infected with T. muris. (E) High levels of prion-specific vacuolation (H\&E), PrP accumulation, reactive astrocytes (GFAP+ cells, brown) and active microglia (AIF1+ cells, brown) were detected in the brains of mice from each infection group. Counterstain, haematoxylin, blue. (F) Upregulated Prnp expression in the mesenteric lymph nodes of T. muris-infected mice. *,$p<0.05$. Panels A and B are adapted from [134] under the terms of the Creative Commons Attribution Licence (CC-BY-4.0; https://creativecommons.org/licenses/by/4.0/). Panels C-E are adapted from [40] under the terms of the Creative Commons Unported Licence (CC-BY-3.0; https://creativecommons.org/licenses/by/3.0/). 
Infection with T. muris, in contrast, is restricted to the large intestine, where it causes significant pathology to the epithelium and lamina propria in the caecum (Figure 4C). Co-infection with T. muris around the time of oral prion exposure coincided with the earlier accumulation of prions ( $\mathrm{PrP}^{\mathrm{Sc}}$ ) within the caecal patches (Figure 4D). Despite this effect, all the co-infected mice developed clinical prion disease with similar neuropathology (Figure 4E), survival times and disease susceptibility to mice infected with prions alone [136]. These data are consistent with findings from experimental mice and natural host species such as sheep, goats and white-tailed deer that show that the GALT in the large intestine (such as the caecal patches) are not early sites of prion replication and neuroinvasion after oral infection [32,136-138]. The low density of M cells in the FAE overlying the large intestinal GALT [139], in addition to the thick mucus layer covering the epithelium at this site [140], is most likely responsible for the relative inability of the large intestinal GALT to acquire particulate antigens such as prions [136].

\subsection{Pathogenic Bacteria}

Oral infection of mice with the pathogenic bacterium $S$. Typhimurium can cause significant pathology and inflammation in the large intestine. The reduced survival times observed in mice co-infected with $S$. Typhimurium were reported to be a consequence of the effects of colitis on the uptake of prions from the gut lumen, or the upregulated expression of $\operatorname{PrP}^{\mathrm{C}}$ in the intestine and mesenteric lymph nodes [101]. However, Prnp expression is also upregulated in the mesenteric lymph nodes during infection of the large intestine with T. muris (Figure 4F) but this was not associated with shortened survival times when co-infected with prions [136]. As mentioned above (Section 6.1), $S$. Typhimurium can inject factors into enterocytes that enhance the abundance of $\mathrm{M}$ cells in the gut epithelium to aid infection [97]. Exposure to bacterial flagellin can also increase the abundance of $\mathrm{M}$ cells in the FAE [98]. Although not tested in the above study [101], the reduced survival times in the mice co-infected with $S$. Typhimurium may also be a consequence of the effects on the abundance of $M$ cells in the small intestinal Peyer's patches.

A fascinating study has described how interactions between $\mathrm{M}$ cells, a specific population of enteric nerves and components of the commensal gut microbiota can together provide protection against oral Salmonella infection [141]. Gut-innervating nociceptors are a specialized subset of sensory neurons that respond to pain and harmful stimuli, and these were found to be closely associated with M cells in Peyer's patches [142]. Furthermore, stimulation from nociceptors, for example following Salmonella infection, could suppress the abundance of M cells in Peyer's patches and this was accompanied by an increased abundance of the commensal, segmented filamentous bacteria (SFB), on the lumenal surface of the FAE [141]. The combined effects of the nociceptor-mediated reduction in $\mathrm{M}$ cell density and increased abundance of SFB on the FAE reduced susceptibility of the mice to oral Salmonella infection [141]. This study raises the intriguing hypothesis that nociceptor-mediated stimulation in response to certain pathogenic microorganisms, harmful stimuli, noxious substances or inflammatory mediators in the small intestine could similarly reduce susceptibility to orally-acquired prion infections.

\section{CNS Prion Disease}

Once the prions enter the brain, their build up ultimately leads to the development of the characteristic spongiform pathology and extensive neurodegeneration in targeted brain regions [143]. CNS prion infections are also accompanied by extensive microglial and astrocyte activation in affected regions [144]. The precise mechanism that causes the neurodegeneration during CNS prion disease remains to be fully understood, but as discussed below, CNS inflammation, or the actions of certain immune cell populations or inflammatory mediators can have a significant impact. For example, although the underlying mechanism was not addressed, prion disease was accelerated in infected mice with concurrent inflammation directly within the CNS caused by the induction of experimental allergic encephalitis (EAE, a commonly used mouse model of multiple sclerosis in humans) [145]. 


\subsection{The Yin and Yang of the Microglia}

The microglia are the resident macrophages of the CNS, and a change in their status from resting to activated is one of the earliest neuropathological features in the brain during prion disease, and occurs before the development of the neuropathology [146-148]. The microglia are established by embryonic day 8 in the brain from yolk sac-derived progenitors, and are mostly maintained by self-renewal in a CSF1R-dependent manner $[149,150]$. Deficiency in the monocyte chemokine receptor CCR2 does not affect microglia abundance or CNS prion disease [151], indicating that the microglial expansion that occurs during prion disease is a consequence of the local proliferation of CNS-resident cells [152]. As the studies described below show, changes to the abundance and phenotype of the microglia in the prion disease-affected brain can affect the rate of the neurodegeneration.

\subsubsection{Microglia Can Phagocytose and Destroy Prions in the Steady State}

The microglia, just like the macrophages in other tissues, are highly phagocytic cells that help remove apoptotic cells (by a process known as efferocytosis) and provide a first line of defence against pathogens. Intracellular accumulations of prions can be detected within microglia in affected brain regions [153], but these cells are not important sites of prion replication [154]. This apparent inability of the microglia to replicate prions may be a consequence of their reduced expression level of Prnp, when compared to neurons and astrocytes [3]. Although it is important to mention that factors other than the magnitude of Prnp are likely to play a role, as the transgenic expression of high levels of Prnp in T cells and B cells was insufficient to sustain prion replication within them $[155,156]$. Instead, data suggest that microglia, like the tissue macrophages, similarly provide host protection by phagocytosing and destroying the prions.

The differentiation, proliferation and survival of microglia and tissue macrophages is controlled by signalling through the cytokine colony-stimulating factor 1 receptor (CSF1R) [157]. Deficiencies in, or pharmacological blockade of CSF1R-signalling, can both block microglia differentiation and survival in the brain. The cytokine IL-34 can also bind to CSF1R, in addition to colony-stimulating factor 1(CSF1), and stimulation via this cytokine similarly plays an essential role in microglia differentiation [158]. A series of studies have shown that the partial ablation of microglia in ganciclovir-treated CD11b-HSVTK mice (transgenic mice expressing thymidine kinase of Herpes simplex virus via the CD11b (Itgam) promoter; [159]), their partial deficiency in IL-34 ${ }^{-/}$mice [159] or their partial deficiency after treatment with a kinase inhibitor (PLX5622) that targets CSF1R [160] (Figure 5) can each accelerate CNS prion disease. These effects coincided with the increased accumulation and deposition of prions in the brain, indicating that the microglia are host protective during CNS prion disease by phagocytosing and destroying prions. However, some important caveats should be considered. Peripheral macrophage and mononuclear phagocytes populations are also ablated to differing extents in the above ablation models, and the influence this has on disease pathogenesis should be considered. For example, although PLX5622 has been widely used to specifically ablate microglia, this treatment also causes long-term effects on the turnover and function of bone marrow-derived, circulating, and tissue-resident macrophages [161]. High levels of lymphotrophic prions also accumulate in the SLO even after their direct injection into the brain by IC injection [56] and subsequently spread back to the brain $[59,80]$. As the accumulation of prions is enhanced in SLO in the absence of tissue macrophages [120,121], their absence in the above models may have contributed to the increased accumulation of prions in the CNS. It is also plausible that the ganciclovir-mediated ablation of the microglia in transgenic CD11b-HSVTK mice triggered an inflammatory cytokine response in the brain, and this may have stimulated a neurotoxic profile in the remaining microglia or other glial cells. 


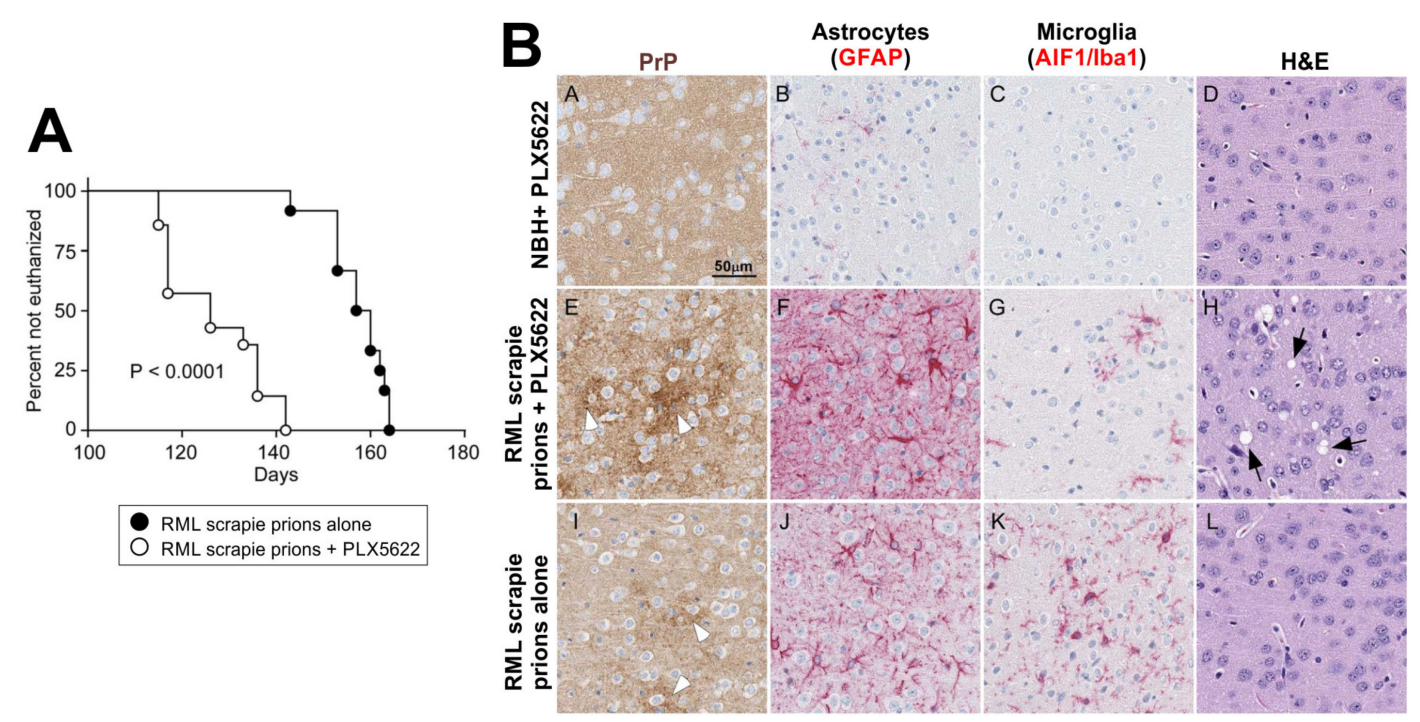

Figure 5. Accelerated CNS prion disease in the absence of microglia. (A) Survival curve shows enhanced onset of clinical prion disease in mice treated with the CSF1R-targeting kinase inhibitor PLX5622. (B) Immunohistochemical analysis shows increased PrP accumulation (brown), reduced abundance of microglia (AIF1/Iba1+ cells, red), increased reactive astrocyte activation (GFAP+ cells, red) and prion-specific vacuolation (arrows, H\&E panel) in PLX5622-treated mice at 100 days after IC injection with RML prions. Adapted with permission from the American Society for Microbiology from [160] (J. Virol. 2018;92:e00549-18, https://doi.org/10.1128/JVI.00549-18).

\subsubsection{Microglia Engulf Apoptotic Bodies}

Milk fat globule epidermal growth factor 8 (MFGE8) is a secreted factor that binds to exposed phosphatidyl serine residues exposed on the surfaces of apoptotic bodies to facilitate their clearance by phagocytic cells, including microglia. CNS prion disease is accelerated in mice deficient in MFGE8 and coincides with the increased accumulation of prions in the brain [162]. This suggests that the clearance of prions by microglia may be mediated via their indirect removal of infected apoptotic neurons. Phagocytes can bind MFGE8-opsonised apoptotic bodies through interactions with the integrins $\alpha v \beta 3$ and $\alpha v \beta 5$. Whether these integrins and other related receptors facilitate the phagocytosis of prions by microglia is uncertain. Triggering receptor expressed in myeloid cells-2 (TREM2) also contributes to the phagocytosis of apoptotic neurons and is upregulated in microglia during prion disease [163]. Signal regulatory protein $\alpha(\operatorname{SIRP} \alpha)$, conversely, acts as a negative regulator of phagocytosis in microglia and other MNP populations [164]. However, prion uptake by microglia occurs independently of TREM2 and $\operatorname{SIRP} \alpha$, as CNS disease is unaltered in transgenic mice that lack these receptors $[163,165]$. Sialoadhesin (CD169) specifically binds to sialylated glycoproteins and is expressed by various MNP populations [166], including activated microglia [167]. Although $\mathrm{PrP}^{\mathrm{Sc}}$ is extensively sialylated [168], deficiency in sialoadhesin similarly does not affect the development of neuropathology during CNS prion disease [169]. Thus, the engulfment of prions by microglia is indirectly mediated via binding to MFGE8 but occurs independently of SIPR $\alpha$, TREM2 and sialoadhesin.

\subsubsection{Microglia Can Cause Neurodegeneration}

Despite the proposed host-protective role for the microglia during CNS prion disease, alterations to their activation status can lead to neurotoxicity. Prion infection in the steady state does not evoke a typical pro-inflammatory cytokine response $[148,168,170]$. The microglial characteristics during the early stages of CNS prion disease are instead similar to the anti-inflammatory profile exhibited by macrophages following their engulfment of apoptotic cells [171]. This is consistent with data showing that CNS prion disease is unaltered in the steady state in mice lacking the NLRP3 inflammasome [172] (essential for release of IL-1 $\beta$ ), NF-KB signalling [173] or MyD88 signalling [174]. Treatment of scrapie-affected sheep with 
the glucocorticoid dexamethasone during the clinical phase similarly had no effect on the development of neuropathology [175]. Modest levels of the anti-inflammatory cytokine TGF- $\beta$ are expressed in the CNS during prion disease $[176,177]$. Whether this cytokine is expressed in the prion disease-affected regions of the brain at sufficient levels to constrain the local induction of pro-inflammatory microglial responses, or mediate neurogenic properties [178] remains to be determined. However, it is interesting to note that when the availability of TGF- $\beta$ in the brain is blocked, this exacerbates the neuropathology [179].

When the accumulation of $\mathrm{PrP}^{\mathrm{Sc}}$, neurodegeneration and microglial phenotype was compared across brain regions in mouse prion disease models, it was noted that the neurodegeneration was restricted to areas of the brain where $\mathrm{PrP}^{\mathrm{Sc}}$ accumulation was also associated with an upregulated innate immune response in the microglia $[147,148,168]$. The precise trigger that mediates the switch in the activation status of the microglia in the steady state is uncertain. However, it is evident that microglia respond to changes in the composition of the carbohydrates displayed on the surface of $\mathrm{PrPS}^{\mathrm{Sc}}$ in such way, that a reduction in sialic acid residue content can induce a pro-inflammatory response [180].

Infection of the brain with prions has been suggested to induce a "primed state" in the microglia that enables these cells to rapidly respond to subsequent exposure to pro-inflammatory stimuli [181]. When the microglia are stimulated in this manner it can have a significant impact on CNS prion disease pathogenesis. For example, central and systemic treatment of mice with LPS during the CNS phase of prion infection triggers the rapid release of pro-inflammatory cytokines and mediators, and this is accompanied by increased microglial activation, increased neurodegeneration and accelerated disease progression [182-184]. This suggests that the microglial response during prion disease favours a homeostatic and potentially pro-resolving/anti-inflammatory phenotype. However, when exposed to pro-inflammatory stimuli such as bacterial LPS, this phenotype appears to be lost, polarising the microglia towards an activated phenotype which can heighten the rate of neurodegeneration. Indeed, as the prion infection proceeds in the brain, the homeostatic transcriptomic signatures in the microglia are replaced by neuroinflammatory signatures [168]. These data show how the effects of systemic and central inflammation on microglial status can exacerbate CNS prion disease.

\subsubsection{Microglia as Therapeutic Targets}

Taken together, these studies raise the suggestion of whether manipulating the abundance or phenotype of microglia may have therapeutic potential during CNS prion disease. One example may include the blocking of environmental cues which stimulate the microglial pro-inflammatory and neurotoxic phenotypes. Ultimately, manipulating the phenotype of the microglia to optimize prion clearance, and likewise the production of pro-resolving factors (including TGF- $\beta$ ) may serve as beneficial factors.

Experiments in mice suggest that such approaches may be beneficial in individuals with a prion infection in the brain, but the wider impacts of long-term administration of immunosuppressive drugs should not be overlooked. One study, for example, has shown how oral treatment with the immunosuppressant FK506 from the onset of the clinical signs was effective in suppressing microglial responses and reducing disease susceptibility in a mouse sCJD model [185]. Inhibition of microglial proliferation or "priming" may also have efficacy. Whereas treatment with the CSF1R kinase inhibitor PLX5622 partially ablates the microglia [160], treatment with the CSF1R-specific kinase inhibitor GW2580 reduces microglial proliferation and skews the cells towards a neuroprotective phenotype [150]. Coincident with the induction of these potentially neuroprotective effects, treatment of mice with GW2580 or an anti-CSF1R blocking antibody, has been shown to slow the rate of neurodegeneration and extend survival times in mice with CNS prion disease [152].

\subsubsection{The Commensal Gut Microbiome Constitutively Modulates Microglia Status}

The mammalian gastrointestinal tract is colonized by a huge and diverse community of commensal microorganisms and is estimated to include over 1000 different bacterial species. These microorganisms and the metabolites they produce provide a range of beneficial and protective effects on their mammalian 
host. These include the production of essential nutrients such as vitamins [186], outcompeting with pathogens [187] and aiding the regulation and development of the immune system $[98,141,188,189]$. An exciting set of studies has also shown how the components of gut commensal microbiota and their metabolites can also modulate the development and function of cells in the CNS, for example by directly stimulating enteric nerves, promoting the release of neuropeptides from enteroendocrine cells or producing important brain bioactive mediators and neurotransmitters including dopamine, serotonin and $\gamma$-aminobutyric acid (reviewed in $[190,191]$ ).

The commensal microbiota also constitutively regulates the development and function of the microglia in the brain. Germ-free mice that completely lack a commensal microbiota have defects in microglia development, differentiation and function, and their response to LPS stimulation or LCMV infection are diminished [192]. Similar effects on microglia status were also observed when conventionally-housed SPF mice were treated with broad-spectrum antibiotics. Disturbances to the commensal microbiota in the intestine have been proposed as risk factors that affect susceptibility and the pathogenesis of many neurodegenerative disorders including Parkinson's disease, Alzheimer's disease, amyotrophic lateral sclerosis and Huntington's disease (reviewed in [193]). The effects of signals from certain bacteria on $\mathrm{T}$ cells in the small intestine can also exacerbate the pathogenesis of EAE in the spinal cords of mice [194], implying a similar pathogenic role for changes to components of the small intestinal microbiota in multiple sclerosis patients.

However, despite the prominent activation and involvement of the microglia in the brain during prion disease, the absence of the commensal microbiota does not affect the development of the neurodegeneration in the steady state $[195,196]$. Whether the microglia in the brains of prion-infected germ-free mice are less sensitive to subsequent neurotoxic activation by pro-inflammatory stimuli remains to be determined. Treatment of prion-infected mice with the tetracycline antibiotics (doxycycline, minocycline and tetracycline) around the onset of the clinical phase has been shown to extend survival times [197]. Tetracycline antibiotics can suppress cytokine synthesis [198] and this might have a beneficial effect on CNS prion disease by reducing systemic inflammation. However, these antibiotics have also been shown to block $\mathrm{PrP}^{\mathrm{C}}-\mathrm{PrP}^{\mathrm{Sc}}$ conversion and neurotoxicity [199].

\subsection{Reactive Astrocytes: Neuroprotective or Neurotoxic?}

Astrocytes are important glial cells that provide homeostatic support to neurons in the steady state. For example, these cells can induce the formation of excitatory synapses through production of mediators such as thrombospondins, SPARC-like 1 and glypicans [200,201]. Astrocytes can also prune synapses to refine neural circuitry to ultimately modulate synaptic plasticity [202]. However, dysfunctional and reactive astrocytes can gain neurotoxic properties following brain injury in the ageing brain and in certain neurodegenerative disorders [203,204].

The contrasting neuroprotective and neurotoxic properties of reactive astrocytes imply that, just like the microglia, these cells may similarly have contrasting roles during CNS prion infections: on the one hand providing homeostatic support to infected/damaged neurons, while on the other hand causing neurotoxicity and driving neuronal death. For example, the production of MFGE8 by astrocytes aids the phagocytosis and clearance of prion-infected and apoptotic neurons by microglia in some mouse strains [162]. However, it is important to note that reactive astrocytes are also capable of phagocytosing apoptotic neurons [205], challenging the conclusion that the phagocytosis and clearance of prions in the brain is restricted to the microglia [159,160]. Unlike the microglia [154], astrocytes may also be important sources of prion replication in the brain [206].

The accumulation of misfolded $\mathrm{PrP}^{\mathrm{Sc}}$ in the brain during prion disease triggers the unfolded protein response (UPR) [207]. This alters the astrocyte secretome, reduces their synaptogenic properties and stimulates the production of neurotoxic factors which together enhance the rate of neurodegeneration [203]. Specifically, phosphorylation of PERK signalling in astrocytes causes the transient shutdown of protein synthesis via phosphorylation of eIF2 $\alpha$. The pharmacological targeting of certain signalling pathways in astrocytes has been shown to have efficacy in reducing hypoxia-induced CNS edema [208]. 
Similar pharmacological targeting of PERK signalling in astrocytes in mice can provide neuroprotection during CNS prion disease, providing an indication that treatments that modulate the phenotype of the reactive astrocytes may have therapeutic potential [203].

\subsubsection{Microglia Can Modify the Phenotype of Reactive Astrocytes}

Astrocytes and the microglia can interact with each other in the brain through direct contact and production of secretory factors [209]. For example, astrocyte-derived CSF1/IL-34, TGF- $\beta 2$ and cholesterol are essential for microglial survival [210]. The reactive astrocytes have been classified into two main functional and transcriptional subclasses. The A1 subclass of reactive astrocytes appear to exhibit neurotoxic properties, whereas the A2 astrocytes produce neurotrophic factors and can provide neuroprotection [211]. A seminal study has shown how contact with microglia and microglia-derived factors is essential for the induction of A1 neurotoxic reactive astrocyte activation [211]. For example, the production of the cytokines TNF- $\alpha$, IL-1 $\alpha$ and complement component C1q by the microglia in response to systemic LPS treatment predominantly induce an A1 phenotype and transcriptomic response in the reactive astrocytes [211]. In the absence of microglia (Csf1r ${ }^{-/}$mice) or these microglial-derived factors, the LPS-mediated induction of A1 astrocytes is blocked. The A1 reactive astrocytes that are induced by systemic LPS treatment also have a distinct transcriptomic signature from the A2 subset [211] (Figure 6A). While the administration of LPS does not itself appear to induce significant neurotoxicity, data indicate that neuronal injury is required for these cells to become susceptible to astrocyte-mediated cytotoxicity [212]. Whereas the expression of certain A1 reactive astrocyte-associated genes has been reported during the preclinical phase of prion disease, this polarity is lost as the infection proceeds towards the terminal stage $[177,213]$. Although the reactive astrocytes in the prion disease-affected brain have been suggested to be neurotoxic [203], they display a mixed A1 and A2 transcriptomic signature [177,214] and notably express high levels of CD44 [215] and complement component C3 $[203,214]$ (Figure 6B-D). Whereas CNS prion disease was unaltered in mice deficient in TNF- $\alpha[216,217]$ or C1q $[65,66]$, the combined deficiency in TNF- $\alpha$, IL- $1 \alpha$ and C1q was shown to accelerate the disease [214]. Although complement C3 expression was reduced in the astrocytes in the infected mice with a combined deficiency in these microglial-derived factors, this had little effect on GFAP expression or the transcriptomic signature of the reactive astrocytes [214] (Figure 6B). This suggests that in the steady state, factors independent of microglial-derived TNF- $\alpha$, IL-1 $\alpha$ and C1q are required for the activation of astrocytes in the prion disease-affected brain.

Further studies are required to determine whether microglia are required for induction of complement component $\mathrm{C} 3+$ reactive astrocytes during prion disease. When microglia were partially ablated using the CSF1R-targeting kinase inhibitor PLX5622, the overall expression of A1 and A2 reactive astrocyte-associated transcripts in the brains of mice infected with prions was enhanced [177]. This suggests a potential additional neuroprotective role for the microglia in the prion disease-affected brain by limiting neurotoxic reactive astrocyte activation. However, it is important to note that the retention of just $5 \%$ microglia after treatment with the CSF1R-targeting kinase inhibitor PLX3397 was sufficient to induce A1 reactive astrocyte activation after systemic LPS treatment [211] (Figure 6A). Transmissions to mice with a complete and specific deficiency in microglia will help to resolve this issue [218]. 


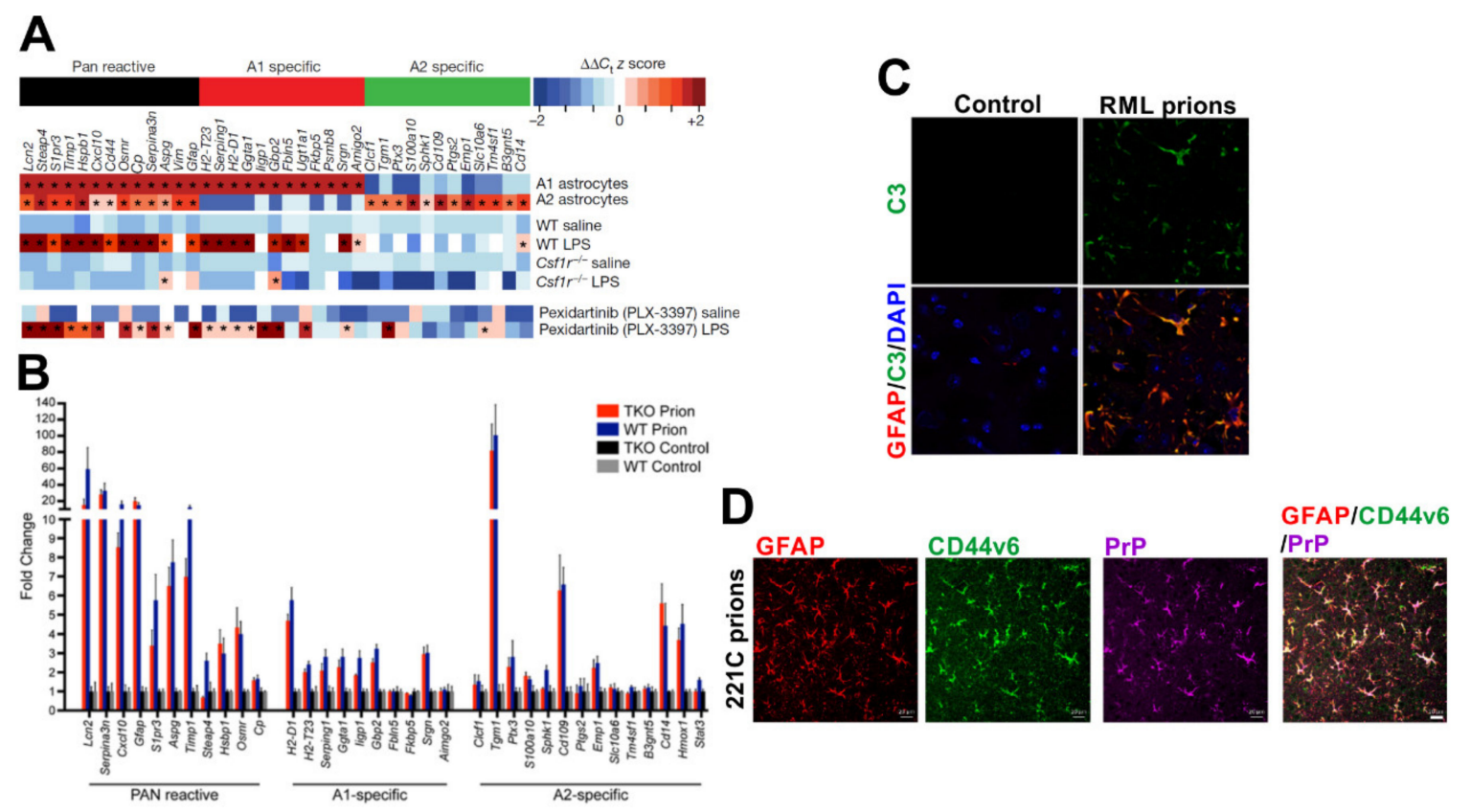

Figure 6. Induction of a mixed A1 neurotoxic and A2 neuroprotective reactive astrocyte phenotype during CNS prion disease. (A) Systemic LPS treatment induces an A1 neurotoxic transcriptional signature in reactive astrocytes in the brain. In microglia-deficient $\mathrm{Csfl}^{-1-}$ mice the LPS-mediated induction of A1 neurotoxic reactive astrocytes is blocked. However, A1 neurotoxic reactive astrocytes are still induced after microglia-depletion by PLX-3397 treatment ( 95\% reduction) [211]. (B) A mixed A1 neurotoxic and A2 neuroprotective reactive astrocyte transcriptional signature was observed in the reactive astrocytes in the brains of wild-type (WT) mice terminally affected with RML prions. Deficiency in the microglial-derived factors TNF- $\alpha$, IL-1 $\alpha$ and C1qa (TKO) had little influence on the induction of this response [214]. (C) Immunofluorescence microscopy shows that GFAP+ (red) reactive astrocytes express high levels of complement component C3 (green) in the prion disease-affected brain [214]. Nuclei detected with DAPI (blue). (D) Immunofluorescence microscopy shows that GFAP+ (red) reactive astrocytes with abundant disease-specific PrP (magenta) express high levels of CD44 variant 6 (green) in the prion disease-affected brain [215]. Panel A is adapted from [211] with permission from the Nature Customer Service Centre GmbH (Liddelow SA et al. Neurotoxic astrocytes are induced by activated microglia. Nature 2017;541:481-487, https://doi.org/10.1038/nature21029). Panels B and C are adapted from [214] under the terms of the Creative Commons Licences (CC-BY-4.0; https://creativecommons. org/licenses/by/4.0/, and CC0-1.0; https://creativecommons.org/publicdomain/zero/1.0/). Panel D is adapted from [215] under the terms of the Creative Commons Attribution Licence (CC-BY-4.0; https://creativecommons.org/licenses/by/4.0/).

\subsubsection{Systemic Inflammation and Reactive Astrocyte Activation During Prion Disease}

The demonstration that the effects of systemic LPS treatment on microglia can indirectly induce neurotoxic A1 reactive astrocyte activation [211] raises the possibility that pro-inflammatory mediators could have a significant impact on reactive astrocyte phenotype and neurodegeneration during prion disease. Systemic LPS treatment, for example, enhances neuronal apoptosis in the brains of mice infected with prions, and accelerates disease progression [182-184]. The effects of systemic LPS treatment on CNS prion disease coincide with the enhanced abundance and inflammatory activation of the microglia, as well as elevated production of the pro-inflammatory cytokines TNF- $\alpha$, IL-1 $\beta$ and IL-6, and cytotoxic mediators such as nitric oxide [182-184]. These experiments were published before the demonstration that LPS treatment also induced neurotoxic A1 reactive astrocyte activation [211]. However, a subsequent study showed that the reactive astrocytes in the brains of infected mice centrally-treated with either TNF- $\alpha$ or IL-1 $\beta$ also had enhanced chemokine responses and increased nuclear localisation of the transcription factor NF-kB [219]. 
The effects of systemic inflammation on the reactive astrocytes could each have a significant impact on CNS prion disease. To investigate this further we analysed mRNA micro-array expression data from a published study of the effects of systemic LPS treatment on the hippocampus of mice infected with ME7 scrapie prions (NCBI GEO accession no: GSE23182; [184]). Here, the mice were systemically injected (IP) with LPS before the terminal phase of prion disease (at 18 weeks post-IC injection with prions). Parallel sets of mice were injected with PBS or normal brain homogenate as controls. This analysis also revealed a predominantly A1-reactive astrocyte-associated transcriptional signature in the hippocampus during the pre-terminal phase of prion disease (prions + PBS; Figure 7), consistent with published studies $[177,213]$. Importantly, this transcriptional signature was significantly enhanced after LPS treatment (prions + LPS; Figure 7). As anticipated [211], the systemic treatment of uninfected mice with LPS (NBH + LPS) also induced the expression of pan- and A1-reactive astrocyte-associated transcripts with limited induction of A2- reactive astrocyte-associated transcripts. However, this polarity was not observed in prion-infected mice after LPS treatment. Instead, LPS treatment was accompanied by the elevated expression of pan-, A1- and A2-reactive astrocyte-associated transcripts (prions+LPS; Figure 7). This analysis illustrates how peripheral exposure to pro-inflammatory stimuli such as bacterial LPS could have a significant impact on the phenotype of the reactive astrocytes in the brains of individuals infected with prions. Furthermore, the neuronal damage caused by CNS prion disease may render the infected neuron more susceptible to LPS-induced astrocyte-mediated cytotoxicity [212]

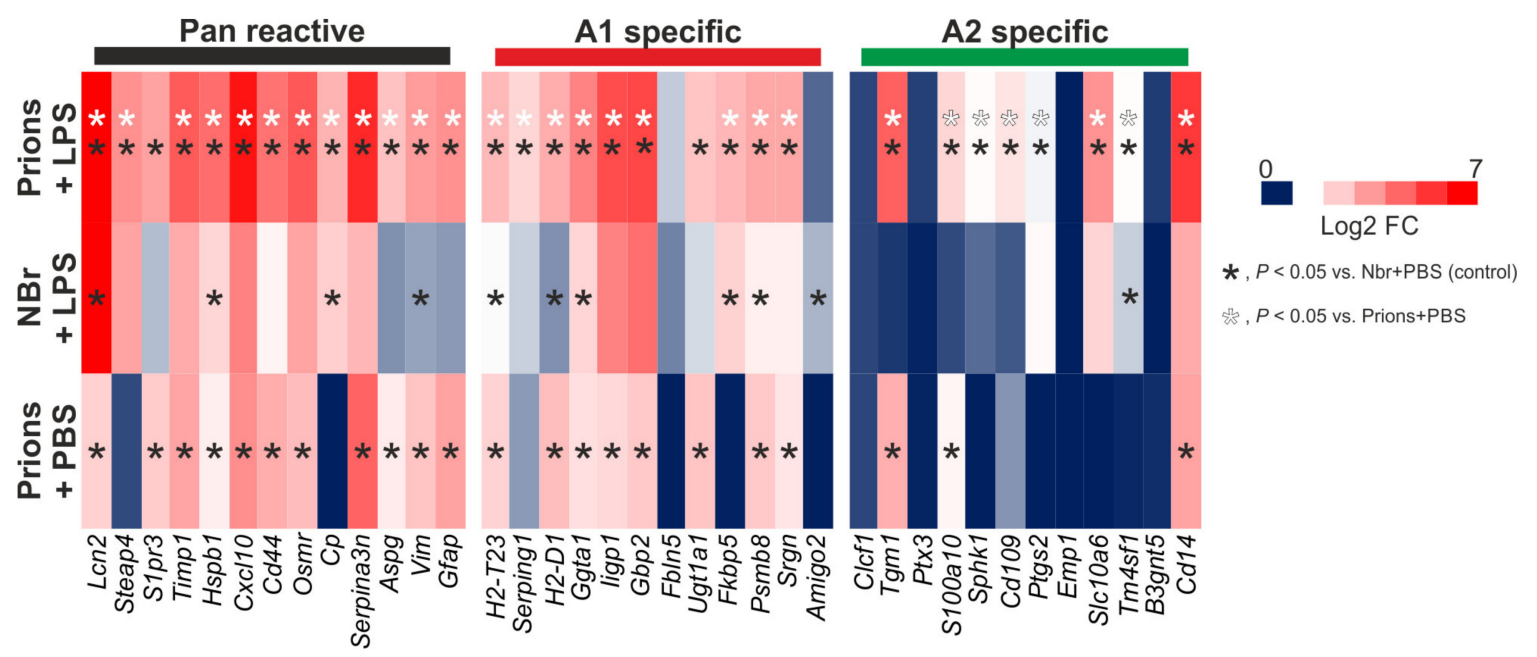

Figure 7. Systemic LPS treatment elevates the expression of pan-, A1 neurotoxic- and A2 neuroprotective reactive astrocyte-associated genes in the hippocampus of mice infected with ME7 scrapie prions. Analysis of a published microarray dataset (NCBI GEO accession no: GSE23182; [184]) of the effects of LPS treatment on astrocyte-associated gene expression in the brains of mice infected with prions. Mice were systemically injected (IP) with at 18 weeks post-IC injection with prions. Hippocampi were removed $6 \mathrm{~h}$ later and gene expression compared by microarray. Parallel sets of mice were injected with PBS or normal brain homogenate (NBr) as controls. Heatmap shows log2 fold change when compared to uninfected control mice injected with PBS. $n=3$ mice/group.

The precise consequences that these LPS-induced effects on the reactive astrocyte transcriptome have on CNS prion disease are uncertain and require further study. Similarly, experiments are also required to determine whether these effects are a consequence of the indirect effects of LPS-stimulation on the microglia [211], or cell-intrinsic responses in the astrocytes themselves, or a combination of the two. While the expression of specific sets of transcripts can be helpful markers to classify cell phenotype [211], their roles in A1- and A2-reactive astrocyte activation also remains to be determined. Despite these uncertainties, this analysis clearly shows that systemic inflammation such as that induced by exposure to LPS can have a significant impact on the reactive astrocytes during CNS 
prion disease. Other stimuli including the cytokine GM-CSF can also promote the pathogenic activation of astrocytes [220], and could similarly have the potential to exacerbate CNS prion disease.

\subsection{Pathogen Co-Infection Can Modify CNS Prion Disease}

\subsubsection{Virus Co-Infections}

Studies have revealed how host cellular responses or the pathology caused by certain viral co-infections can affect CNS prion disease pathogenesis. For example, mice succumbed to infection with the Chandler mouse-passaged scrapie isolate much earlier when given a respiratory adenovirus infection towards the clinical phase [221]. Piry virus infection in mice causes a non-lethal arbovirus encephalitis in regions of the brain including the hippocampus. Co-infection of with Piry virus altered the morphology of the microglia in the brains of mice with CNS prion disease. These cells displayed an enhanced ramified appearance, but this did not affect the neurodegeneration or clinical signs [222]. Peripheral co-infection with an apathogenic murine retrovirus (molecular clone Mov3 of Moloney murine leukaemia virus) was also associated with enhanced microglial activation in the brains of mice infected with RML scrapie prions [223]. Here, the enhanced microglial activation in the co-infected mice was accompanied by increased prion clearance and increased lysosomal-autophagy activation in the microglia. However, the effect of retrovirus co-infection on CNS prion disease was transient, as the disease kinetics returned to levels similar to mice infected with prions alone when the microglial activation had declined [223].

Infection with the Friend retrovirus complex can also enhance reactive astrocyte activation in the brains of mice infected with prions [224]. However, the effect this had on disease pathogenesis is uncertain, because although the clinical presentation was altered in the co-infected mice, survival times were not.

\subsubsection{Gastrointestinal Helminth Parasites}

Little is known of underlying molecular mechanisms responsible for the effects that the virus co-infections described above have on prion disease pathogenesis in the brain. However, a recent study gives insight into how the production of pro-inflammatory cytokines in response to co-infection with a gastrointestinal helminth parasite could accelerate CNS prion disease [213]. The natural mouse gastrointestinal helminth pathogen T. muris establishes infection exclusively in the large intestine. When C57Bl/6J mice are infected with a high dose of infective T. muris eggs (ca. 200) this induces a protective CD4+ T helper cell type 2 (Th2)-polarized immune response. Conversely, when the mice are infected with a low dose of ca. 20 infected eggs this stimulates a non-protective parasite-specific Th1-polarized response that includes the production of the pro-inflammatory cytokine interferon (IFN)- $\gamma[213,225,226]$ (Figure 8A). Co-infection of C57Bl/6J mice with a low dose of T. muris accelerated clinical prion disease (Figure $8 \mathrm{~B}$ ). The effects of T. muris co-infection on CNS prion disease were specific to an IFN- $\gamma$-mediated systemic response, as co-infection with a high parasite dose that induced a Th2 response had no effect [213]. The accelerated prion disease in the T. muris co-infected mice coincided with the enhanced expression of certain A1 astrocyte-associated genes [213] (Figure 8C). Stimulation of astrocytes with IFN- $\gamma$ can induce neurotoxic activity [227]. Since the reactive astrocytes in the co-infected mice specifically expressed high levels of IFN- $\gamma$ receptor 1 (IFNGR1), this suggested that the IFN- $\gamma$ produced in response to the parasite infection in the intestine had enhanced the neurotoxic phenotype of the reactive astrocytes (Figure 8D). Elevated IFNGR1 expression was also detected in reactive astrocytes in mice infected with prions alone [213]. However, since IFN- $\gamma$ is not induced in mice infected with prions alone in the steady state $[213,228]$, the induction of IFNGR1 in the reactive astrocytes in response to CNS prion disease most likely primes them to respond to subsequent IFN- $\gamma$-mediated stimulation. Furthermore, the A1 astrocyte-associated genes Gbp 2 and Psmb8 are each inducible in astrocytes by IFN- $\gamma$ stimulation $[229,230]$. 
A

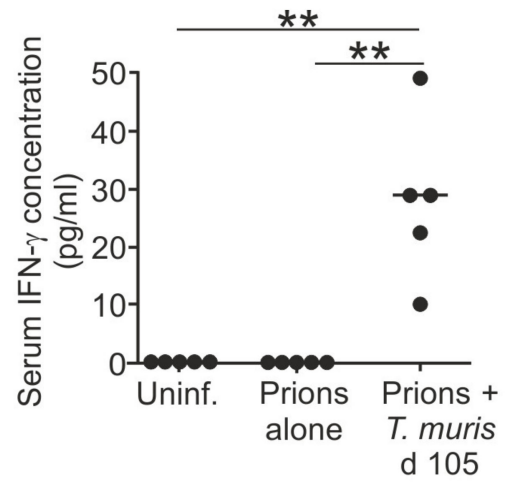

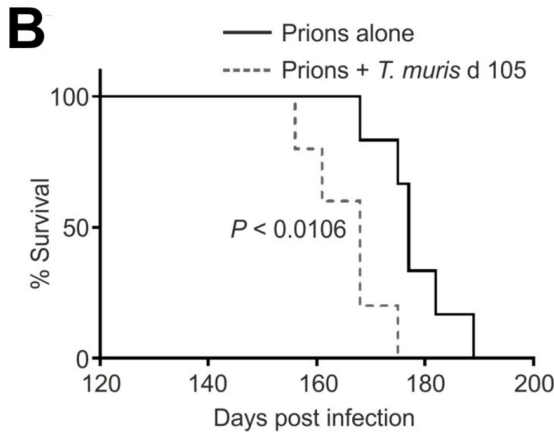
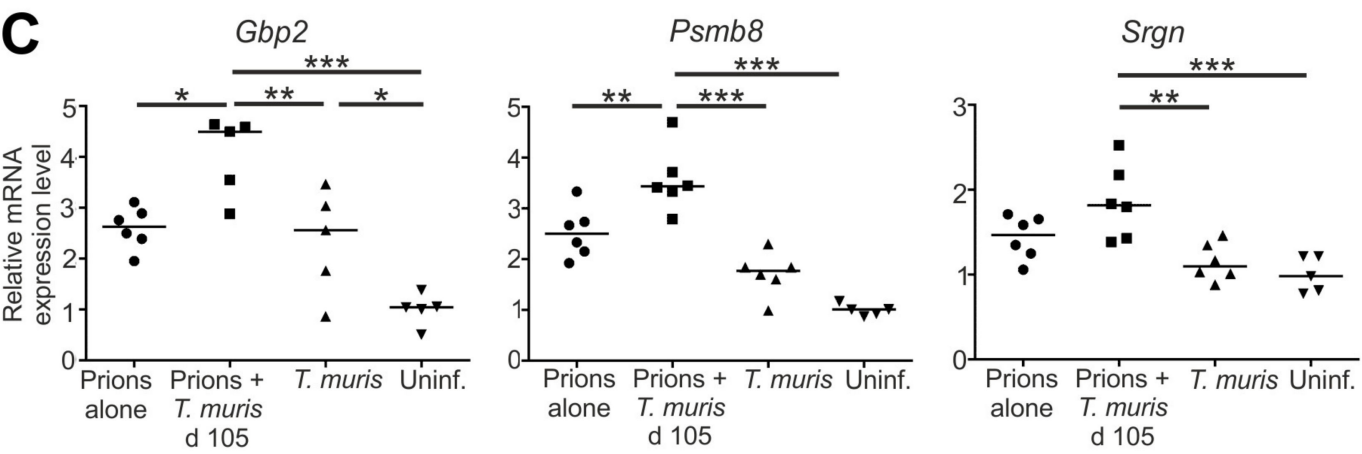

D

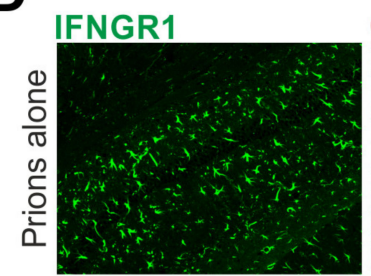

GFAP

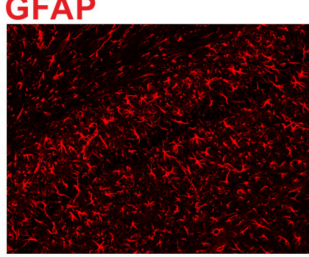

IFNGR1/GFAP

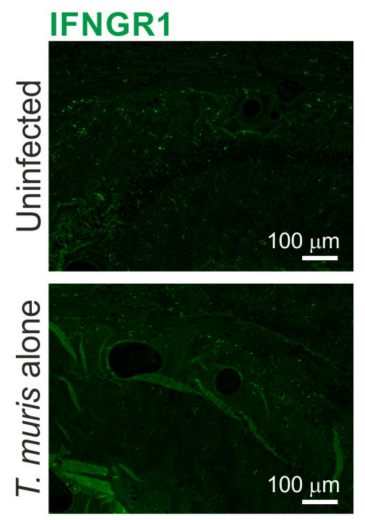

Figure 8. Accelerated CNS prion disease in mice co-infected with a gastrointestinal helminth during the preclinical phase [213]. Mice were injected IC with ME7 scrapie prions and 105 days later they were orally co-infected with $\sim 20$ infective T. muris eggs. Mice were sampled 35 days later (d 140) or maintained until the development of clinical disease. (A) High levels of IFN- $\gamma$ in the serum of mice co-infected with prions and T. muris. (B) Survival plot shows accelerated onset of clinical prion disease in mice co-infected with prions and T. muris. (C) Significantly increased expression of the A1 reactive astrocyte-associated genes Gbp2, Psmb8 and Srgn in the brains of mice co-infected prions with T. muris. (D) Immunofluorescent microscopical detection of high levels of IFNGR1 (green) in GFAP+ reactive astrocytes (red) in the brains of mice infected with prions alone or co-infected with prions and T. muris. ${ }^{*}, p<0.05 ;{ }^{* *}, p<0.01 ;{ }^{* * *}, p<0.001$. Figure adapted from [213] under the terms of the Creative Commons Attribution Licence (CC-BY-4.0; https://creativecommons.org/licenses/by/4.0/).

Although low numbers of CD4+ and CD8+ T cells can infiltrate the brain during CNS prion disease [53], these cells are unlikely to contribute to the neurodegeneration in the steady state [28,30,231]. Interestingly, co-infection with T. muris also appeared to enhance the abundance of CD8+ T cells in the brains of mice infected with prions. It is plausible that IFN- $\gamma$-mediated stimulation in the co-infected mice enhanced the permeability of the blood-brain barrier enabling these cells to access the CNS [232]. CD8+ T cells with a pro-inflammatory and cytotoxic transcriptome have also been detected 
in the cerebrospinal fluid and brains of Alzheimer's disease patients [233]. Other disturbances to the gastrointestinal tract could also affect the abundance of potentially pathogenic $T$ cells in the intestine and have pathological consequences in the CNS. For example, factors produced by certain bacteria strains in the small intestine can induce autoreactive $T$ cells and this is associated with enhanced EAE severity [194]. Further studies are required to explore whether the CD8+ T cells that infiltrate the brains of mice co-infected with prions and T. muris also have pathogenic properties.

Infections with gastrointestinal helminth pathogens are common in natural prion disease-susceptible host species. For example, the nematode parasite Teladorsagia circumcincta causes infection in the abomasum of sheep. When lambs with natural sheep scrapie were co-infected with T. circumcincta during the preclinical phase, this also coincided with shortened prion disease survival times [135]. The effects of the helminth co-infection on the rate of development of the neuropathology were not determined in this study. However, this study raises the possibility that the systemic release of inflammatory mediators in response to helminth infection in the abomasum may have similarly accelerated the development of neuropathology within the CNS.

\subsection{The Contrasting Effects of Type I Interferons}

The production of type I IFN (IFN- $\alpha$ and IFN- $\beta$ ) provides an important first line of defence in host cells against viral infections. However, their production in the brain can have diverging consequences and has been linked to both protective, anti-inflammatory and detrimental effects (reviewed in [234]). Similarly contrasting roles for type I interferons during CNS prion disease have also been reported. Data from one laboratory suggested that type I IFN-mediated signalling via the IFN- $\alpha$ receptor 1 (IFNAR1) may have pathological consequences during CNS prion disease in the steady state, as survival times were extended in Ifnar $1^{-1-}$ mice infected with ME7 scrapie prions [235]. Here, the absence of type I IFN signalling during CNS prion disease coincided with suppressed microglial and astrocytic activation, as well as reduced phagocytic activity in the microglia in areas of the brain associated with neurodegeneration. The endoplasmic adaptor molecule, stimulator of IFN genes (STING), is a cytosolic sensor of DNA damage and endoplasmic reticulum stress and a potent inducer of type I IFN [236]. In the absence of STING the production of IFN- $\beta$ by microglia from the brains of prion-infected mice was blocked. This implies that the STING-mediated detection of damaged neurons by microglia stimulates the production of type I IFN production during CNS prion disease, and this may enhance the rate of neurodegeneration [235]. However, it is important to note that induction of IFN- $\beta$ has not been observed in patients with SCJD or in independent studies of mice infected with ME7 scrapie prions [237,238].

Conversely, data from another series of studies have proposed that type I IFN may play a protective role $[239,240]$. In contrast to data above [235], prion disease developed earlier in Ifnar $1^{-/-}$mice infected with 22L scrapie prions, whereas treatment with a type I IFN antagonist (RO8191) extended survival times [240]. The reasons behind these discrepancies are not immediately apparent, but further studies may help to identify specific type I IFN regulators that influence the rate of development of CNS prion disease in certain individuals.

\subsection{COVID-19}

Infection with the severe acute respiratory syndrome coronavirus 2 (SARS-CoV-2) causes coronavirus disease 2019 (COVID-19) [241]. This highly infectious disease has rapidly spread worldwide and, at the time of writing (August 2020) had been attributed to at least 240,000 deaths [242]. A striking characteristic of this infection in the UK was that $>90 \%$ of COVID-19-related deaths in the UK occurred in individuals who were $>60$ years old [243]. In these patients, dementia was identified as a highly significant co-morbidity factor for risk of hospitalized COVID-19 and death [244,245]. Whether COVID-19 enhances the progression of the neurodegeneration in these elderly individuals remains to be determined. However, a range of studies have discussed how systemic infection and gastrointestinal infections could exacerbate the cognitive decline or neuropathology in patients 
with Alzheimer's disease [246,247], Parkinson's disease [248] and amyotrophic lateral sclerosis or frontotemporal dementia [249].

A recent case report of a $>60$-year-old patient reported that the onset of clinical sCJD signs occurred concurrently with those of COVID-19 [250]. Further studies are clearly necessary to investigate this association, and coincidence cannot be entirely excluded. However, considering data discussed in the above sections, it is tempting to speculate that the strong inflammatory responses that have been described in patients with severe COVID-19 disease [251] could exacerbate the neuropathology. For example, viral load in COVID-19 patients correlates highly with serum TNF- $\alpha$ levels, and severe COVID-19 disease is associated with high serum TNF- $\alpha$ [251]. As described above (Section 9.2.1), TNF- $\alpha$ is an important inducer of neurotoxic A1 reactive astrocytes in the brain [211]. Furthermore, TNF- $\alpha$ administration exacerbates the clinical signs in mice infected with prions [252] and exaggerates the reactive astrocyte activation [219]. Viral load in COVID-19 patients also correlates highly with serum IFN- $\gamma$ levels [251], and those requiring intensive care treatment have high serum IFN- $\gamma$ levels [253]. This cytokine can similarly stimulate neurotoxic reactive astrocyte activation [227], and IFNGR1 expression is upregulated in reactive astrocytes during CNS prion disease [213], in aging human brains and patients with Parkinson's disease and Alzheimer's disease $[227,254]$. Thus, it is plausible that the systemic production of high levels of pro-inflammatory mediators such as TNF- $\alpha$ and IFN- $\gamma$ in response to infection with the SARS-Cov-2 virus could accelerate the neurodegeneration in patients with concurrent prion disease or other neurodegenerative disorders.

\section{Conclusions}

Despite decades of intensive research, there are still no effective treatments that can be used to block prion disease susceptibility or intervene in the disease process. As a consequence, the onset of clinical prion disease is invariably fatal in affected individuals. Many of the studies discussed throughout this review show how modulation of immune cell abundance or function can have protective effects on prion disease pathogenesis and susceptibility. Similar changes, either around the time of prion exposure or towards the clinical phase, could influence an individual's risk of being infected and developing disease. This could explain why some individuals develop clinical disease and others do not, despite exposure to similar amounts of prions. For example, the UK population is likely to have been widely exposed to the BSE agent through the consumption of contaminated food during the BSE epidemic. Despite this, the incidence of probable and definite clinical vCJD cases has fortunately been relatively low. Since data from BSE transmission to transgenic mice expressing human $\operatorname{PrP}^{\mathrm{C}}$ indicate that there is a significant barrier to the cross-species transmission of BSE prions to humans (known as the species barrier effect) [255], it is feasible that, in some individuals, the effects of inflammation around the time of exposure may have increased their susceptibility to oral prion infection.

Conversely, a range of studies have raised the credible prospect that immunotherapeutic approaches, such as passive or active immunisation, may have efficacy against these currently untreatable and devastating disorders (reviewed in [256,257]). For example, transgenic mice that are engineered to secrete anti-PrP antibodies are protected against peripheral prion infections [258]. Passive immunisation with monoclonal anti-PrP antibodies is similarly protective in mice but large quantities of anti-PrP antibodies were administered for the duration of the experiment [259]. At the time of writing, a clinical trial in the UK was underway to test the efficacy of anti-PrP antibody treatment (using monoclonal antibody PRN100) in six SCJD patients [260]. Of course, the blood-brain barrier limits the entry of large blood-borne molecules such as antibodies into the brain [261]. Therefore, to be effective against the CNS phase of prion disease, these must be administered directly into the CNS of affected individuals, although use of camelid-derived PrP-specific heavy chain antibodies, or nanobodies, may offer an alternative approach [262].

However, since each of these examples involve the administration of antibodies against the PrP molecule, the potential for them to bind to cellular $\operatorname{PrP}^{\mathrm{C}}$ (especially on neurons) and cause autoimmunity or neurotoxicity must be considered $[263,264]$. Fortunately a detailed assessment of the impact of the 
binding of anti-PrP antibodies to different domains of the $\operatorname{PrP}^{\mathrm{C}}$ molecule offers useful advice for future antibody-based treatments: antibodies that bind to the globular protein domain can be neurotoxic, whereas those that bind to the flexible tail of $\mathrm{PrP}^{\mathrm{C}}$ appear to be neuroprotective [263]. Antibodies are considered to provide protection through mechanisms including the elimination of prions from affected tissue or blocking $\mathrm{PrP}^{\mathrm{C}}-\mathrm{PrP}^{\mathrm{Sc}}$ conversion. However, stimulation with certain anti-PrP antibodies can induce anti-inflammatory macrophage polarisation and, by doing so, protect mice from an otherwise lethal influenza infection [10]. It will be interesting to determine whether similar anti-PrP antibody-mediated effects could indirectly limit the neurotoxic activation of microglia during prion disease [147,168].

Prion disease has been transmitted in natural host species, including humans, via the oral route after ingestion of food or pasture contaminated with prions (discussed in [16]). An effective anti-prion vaccine will therefore need to induce both mucosal (IgA) response and systemic (IgG) antibody responses to protect against prion invasion from the intestine and the subsequent effects of prion accumulation in tissues. Fortunately, experimental studies in mice and white-tailed deer have provided proof of principle that mucosal immunisation against $\operatorname{PrP}^{C}$ can provide partial protection against orally-acquired prion disease $[265,266]$. The enterocytes that line the intestine can transcytose IgG into the intestinal lumen, and can subsequently transport IgG-antigen complexes back across the epithelium by a process known as reverse transcytosis [267]. It remains to be determined whether anti-PrPC antibodies might in some instances enhance the transcytosis of prions across into Peyer's patches and by doing so increase disease susceptibility [268].

Finally, natural, rare instances of high-titre, anti-PrPC antibodies have been detected in the bloodstream of some humans. In one study, serum samples were analysed from 128 individuals with various pathogenic prion disease-associated PRNP mutation and 78 control individuals that lacked these mutations but had a positive family history of genetic prion disease [269]. While disease-associated PRNP mutations did not generally stimulate antibody responses to $\operatorname{Pr} \mathrm{P}^{\mathrm{C}}$, some individuals in this study did have anti-PrPC antibodies (IgG subclass) in their sera. However, the presence and titres of these anti-PrP ${ }^{C}$ antibodies were similar across the subject groups, arguing against them providing protection against prion disease or directly contributing to the neurodegeneration. In a separate study, serum samples from over 48,000 Swiss hospital patients were screened. Amongst this large collection of samples, 21 individuals were identified with potentially-protective high-titre anti-PrP antibody titres [270] (Figure 9A). In some individuals, these titres were maintained for at least 8 months (Figure 9B). An additional genetic screen of large-scale antibody repertoire sequences derived from circulating and naïve B cells from healthy donors also identified the existence of some potentially-protective $\mathrm{PrP}^{\mathrm{C}}$-specific antibody clones [270] (Figure 9C). Further research is now necessary to determine whether these are sufficient to offer in protection to these individuals against prion infections in vivo. The demonstration that potentially-protective anti-PrP antibodies were detected in some individuals without obvious signs of neurotoxicity raises hope that antibody-based intervention strategies against prion diseases may be tolerated without significant adverse reactions. 


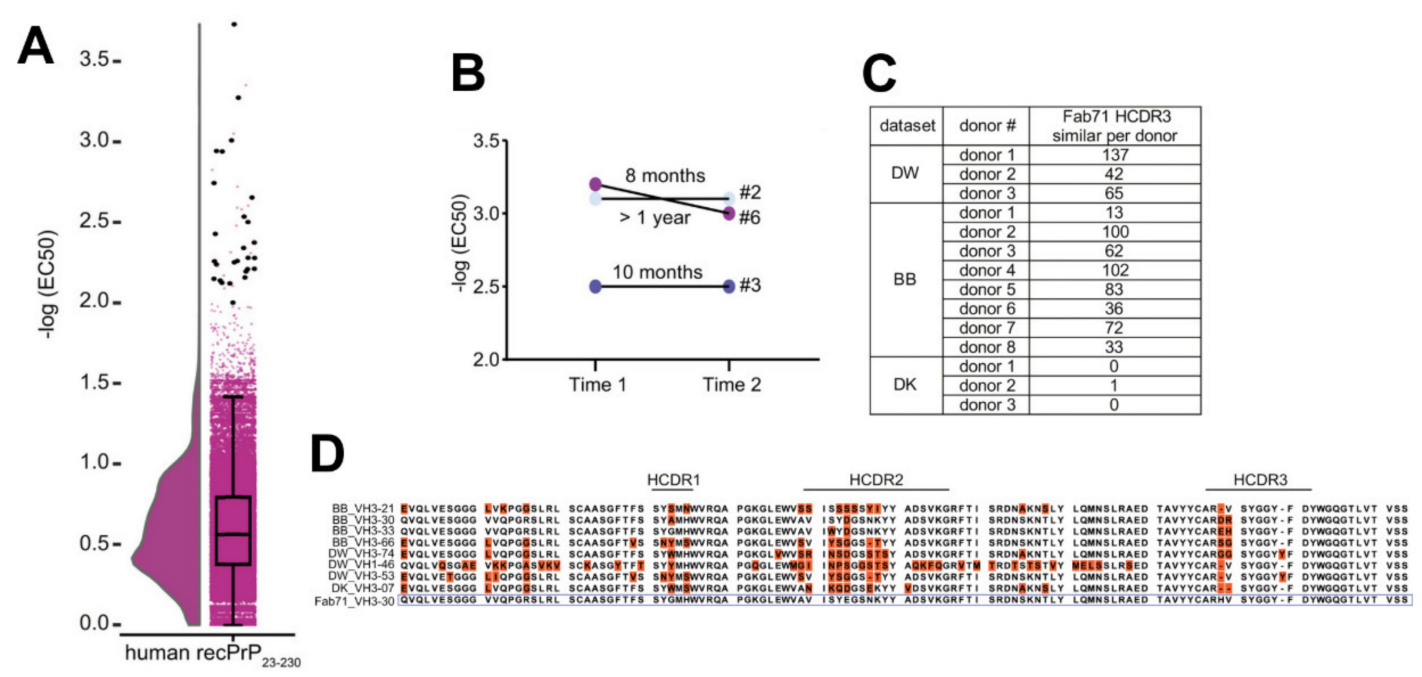

Figure 9. Detection of protective anti-PrP antibodies in human serum and immunoglobulin repertoires [270]. (A) Violin plot/box plot showing detection of 21 individuals (solid black circles) with high-titre anti-PrP antibody titres in serum samples from 41,718 Swiss hospital patients. (B) Anti-PrP reactivity was maintained for at least 8 months in some individuals. (C) Identification of HCDR3 sequences similar to a synthetic phage-derived anti-PrP Fab clone (Fab71) in three different datasets of human antibody repertoires from healthy donors. (D) The amino acid sequence of Fab17 VH3-30 compared to the HCDR3 regions identified in the different healthy donor databases that differed from Fab71 by $\leq 3$ residues. Orange boxes indicate amino acids distinct from Fab71. Adapted from [270] under the terms of the Creative Commons Attribution Licence (CC-BY-4.0; https://creativecommons.org/licenses/by/4.0/).

Author Contributions: Conceptualisation, N.A.M.; all authors contributed to the writing of the original draft, and the review and editing of the final version of the manuscript; funding acquisition, N.A.M. All authors have read and agreed to the published version of the manuscript.

Funding: This research was funded by the Biotechnology and Biological Sciences Research Council, grant numbers BBS/E/D/20002174, BBS/E/D/30002276 and BB/S005471/1. The APC was funded by the Research Council UK Open Access Publication Fund.

Acknowledgments: We thank each of the reviewers of this manuscript for their timely reviews and excellent suggestions. We thank Prof. Shane Liddelow (NYU School of Medicine, New York, NY USA) for helpful discussion.

Conflicts of Interest: The authors declare no conflict of interest. The funders had no role in the design of this review; in the writing of the manuscript, or in the decision to publish.

$\begin{array}{ll}\text { Abbreviations } & \\ \text { BSE } & \text { Bovine spongiform encephalopathy } \\ \text { cDC } & \text { Conventional dendritic cell } \\ \text { CNS } & \text { Central nervous system } \\ \text { CSF1/R } & \text { Colony-stimulating factor 1/receptor } \\ \text { FAE } & \text { Follicle-associated epithelium } \\ \text { FDC } & \text { Follicular dendritic cell } \\ \text { GALT } & \text { Gut-associated lymphoid tissue } \\ \text { GSS } & \text { Gerstmann-Sträussler-Scheinker disease } \\ \text { IC } & \text { Intracerebral } \\ \text { IFN } & \text { Interferon } \\ \text { IFNGR1 } & \text { Interferon gamma receptor 1 } \\ \text { IL } & \text { Interleukin } \\ \text { IP } & \text { Intraperitoneal } \\ \text { LPS } & \text { Lipopolysaccharide } \\ \text { MFGE8 } & \text { Milk fat globule epidermal growth factor 8 }\end{array}$




$\begin{array}{ll}\text { MHC } & \text { Major histocompatibility complex } \\ \text { MNP } & \text { Mononuclear phagocyte } \\ \text { PrPC } & \text { Cellular PrP isoform } \\ \text { PrPSc } & \text { Prion disease-specific PrP isoform } \\ \text { sCJD } & \text { Sporadic Creutzfeldt-Jakob disease } \\ \text { SED } & \text { Subepithelial dome } \\ \text { SFB } & \text { Segmented filamentous bacteria } \\ \text { SLO } & \text { Secondary lymphoid organ } \\ \text { TGF } & \text { Transforming growth factor } \\ \text { TNF } & \text { Tumour necrosis factor } \\ \text { UPR } & \text { Unfolded protein response } \\ \text { vCJD } & \text { Variant Creutzfeldt-Jakob disease }\end{array}$

\section{References}

1. Prusiner, S.B. Novel proteinaceous infectious particles cause scrapie. Science 1982, 216, 136-144. [CrossRef] [PubMed]

2. Bolton, D.C.; McKinley, M.P.; Prusiner, S.B. Identification of a protein that purifies with the scrapie prion. Science 1982, 218, 1309-1311. [CrossRef] [PubMed]

3. Zhang, Y.; Chen, K.; Sloan, S.A.; Bennett, M.L.; Scholze, A.R.; O’Keeffe, S.; Phatnani, H.P.; Guarnieri, P.; Caneda, C.; Ruderisch, N.; et al. An RNA-sequencing transcriptome and splicing database of glia, neurons, and vascular cells of the cerebral cortex. J. Neurosci. 2014, 34, 11929-11947. [CrossRef] [PubMed]

4. Küffer, A.; Lakkraju, A.K.; Mogha, A.; Petersen, S.C.; Airich, K.; Doucerain, C.; Marpakwar, R.; Bakirci, P.; Senatore, A.; Monnard, A.; et al. The prion protein is an agonistic ligand of the G protein-coupled receptor Adgrg6. Nature 2016, 536, 464-468. [CrossRef]

5. Prusiner, S.B.; Groth, D.; Serban, A.; Koehler, R.; Foster, D.; Torchia, M.; Burton, D.; Yang, S.-L.; DeArmond, S.J. Ablation of the prion protein $(\mathrm{PrP})$ gene in mice prevents scrapie and facilitates production of anti-PrP antibodies. Proc. Natl. Acad. Sci. USA 1993, 90, 10608-10612. [CrossRef]

6. Manson, J.C.; Clarke, A.R.; Hooper, M.L.; Aitchison, L.; McConnell, I.; Hope, J. 129/Ola mice carrying a null mutation in PrP that abolishes mRNA production are developmentally normal. Mol. Neurobiol. 1994, 8, 121-127. [CrossRef]

7. Benestad, S.L.; Austbo, L.; Tranulis, M.A.; Espenes, A.; Olsaker, I. Healthy goats naturally devoid of prion protein. Vet. Res. 2012, 43, 87. [CrossRef]

8. Minikel, E.V.; Karczewski, K.J.; Martin, H.C.; Cummings, B.B.; Whiffin, N.; Rhodes, D.; Alfoldi, J.; Trembath, R.C.; van Heel, D.A.; Daly, M.J.; et al. Evaluating drug targets through human loss-of-function genetic variation. Nature 2020, 581, 459-464. [CrossRef]

9. Nakato, G.; Hase, K.; Suzuki, M.; Kimura, M.; Ato, M.; Hanazato, M.; Tobiume, M.; Horiuchi, M.; Atarashi, R.; Nishida, N.; et al. Cutting edge: Brucella abortus exploits a cellular prion protein on intestinal $\mathrm{M}$ cells as an invasive receptor. J. Immunol. 2012, 189, 1540-1544. [CrossRef]

10. Chida, J.; Hara, H.; Uchiyama, K.; Takahashi, E.; Miyata, H.; Kosako, H.; Tomioka, Y.; Ito, T.; Horiuchi, H.; Matsuda, H.; et al. Prion protein signaling induces M2 macrophage polarization and protects from lethal influenza infection in mice. PLoS Pathog. 2020, 16, e1008823. [CrossRef]

11. McCulloch, L.; Brown, K.L.; Mabbott, N.A. Ablation of the cellular prion protein, $\operatorname{PrPC}$, specifcally on follicular dendritic cells has no effect on their maturation or function. Immunology 2013, 138, 246-257. [CrossRef] [PubMed]

12. Caughey, B.W.; Dong, A.; Bhat, K.S.; Ernst, D.; Hayes, S.F.; Caughey, W. Secondary structure analysis of the scrapie-associated protein PrP 27-30 in water by infrared spectroscopy. Biochemistry 1991, 30, 7672-7680. [CrossRef] [PubMed]

13. Bradford, B.M.; Piccardo, P.; Ironside, J.; Mabbott, N.A. Human prion diseases and their risk of transmission during anatomical dissection. Clin. Anat. 2014, 27, 821-832. [CrossRef] [PubMed]

14. Bruce, M.E.; Will, R.G.; Ironside, J.W.; McConnell, I.; Drummond, D.; Suttie, A.; McCardle, L.; Chree, A.; Hope, J.; Birkett, C.; et al. Transmissions to mice indicate that 'new variant' CJD is caused by the BSE agent. Nature 1997, 389, 498-501. [CrossRef] [PubMed] 
15. Hill, A.F.; Desbruslais, M.; Joiner, S.; Sidle, K.C.L.; Gowland, I.; Collinge, J. The same prion strain causes vCJD and BSE. Nature 1997, 389, 448-450. [CrossRef] [PubMed]

16. Mabbott, N. How do PrPSc prions spread between and within host species, and within hosts? Pathogens 2017, 6, 60. [CrossRef] [PubMed]

17. Eklund, C.M.; Kennedy, R.C.; Hadlow, W.J. Pathogenesis of scrapie virus infections in the mouse. J. Infect. Dis. 1967, 117, 15-22. [CrossRef] [PubMed]

18. Clarke, M.C.; Haig, D.A. Attempts to demonstrate neutralising antibodies in the sera of scrapie-infected animals. Vet. Rec. 1966, 19, 647-649. [CrossRef] [PubMed]

19. Porter, D.D.; Porter, H.G.; Cox, N.A. Failure to Demonstrate a Humoral Immune Response to Scrapie Infection in Mice. J. Immunol. 1973, 111, 1407-1410. [PubMed]

20. Tsukamoto, T.; Diringer, H.; Ludwig, H. Absence of autoantibodies against neurofilament proteins in the sera of scarpie infected mice. Tohoku J. Exp. Med. 1985, 4, 483-484. [CrossRef]

21. Fraser, H.; Dickinson, A.G. Pathogenesis of scrapie in the mouse: The role of the spleen. Nature 1970, 226, 462-463. [CrossRef] [PubMed]

22. Dickinson, A.G.; Fraser, H.; McConnell, I.; Outram, G.W. Mitogenic Stimulation of the Host Enhances Susceptibility to Scrapie. Nature 1978, 272, 54-55. [CrossRef] [PubMed]

23. Kimberlin, R.H.; Cunnington, P.G. Reduction fo scrapie incubation time in mice and hamsters by a single infection of methanol extraction residue of BCG. Fems Microbiol. Lett. 1978, 3, 169-172. [CrossRef]

24. Outram, G.W.; Dickinson, A.G.; Fraser, H. Slow encephalopathies, inflammatory responses, and arachis oil. Lancet 1975, 198-200. [CrossRef]

25. Farquhar, C.F.; Dickinson, A.G. Prolongation of scrapie incubation period by an injection of dextran sulphate 500 within the month before or after infection. J. Gen. Virol. 1986, 67, 463-473. [CrossRef]

26. Dickinson, A.G.; Meikle, V.M.; Fraser, H. Genetical control of the concentration of ME7 scrapie agent in the brain of mice. J. Comp. Pathol. 1969, 79, 15-22. [CrossRef]

27. Junt, T.; Scandella, E.; Ludewig, B. Form follows function: Lymphoid tissue microarchitecture in antimicrobial immune defence. Nat. Rev. Immunol. 2008, 8, 763-775. [CrossRef]

28. Fraser, H.; Dickinson, A.G. Studies of the lymphoreticular system in the pathogenesis of scrapie: The role of spleen and thymus. J. Comp. Pathol. 1978, 88, 563-573. [CrossRef]

29. Kitamoto, T.; Muramoto, T.; Mohri, S.; Doh-Ura, K.; Tateishi, J. Abnormal Isoform of Prion Protein Accumulates in Follicular Dendritic Cells in Mice with Creutzfeldt-Jakob Disease. J. Virol. 1991, 65, 6292-6295. [CrossRef]

30. Klein, M.A.; Frigg, R.; Flechsig, E.; Raeber, A.J.; Kalinke, U.; Bluethman, H.; Bootz, F.; Suter, M.; Zinkernagel, R.M.; Aguzzi, A. A crucial role for B cells in neuroinvasive scrapie. Nature 1997, 390, 687-691. [CrossRef]

31. Kimberlin, R.H.; Walker, C.A. The role of the spleen in the neuroinvasion of scrapie in mice. Virus Res. 1989, 12, 201-211. [CrossRef]

32. van Keulen, L.J.; Schreuder, B.E.; Vromans, M.E.; Langeveld, J.P.; Smits, M.A. Pathogenesis of natural scrapie in sheep. Arch. Virol. Suppl. 2000, 16, 57-71.

33. van Keulen, L.J.M.; Vromans, M.E.W.; van Zijderveld, F.G. Ealry and late pathogenesis of natural scrapie infection in sheep. APMIS 2002, 110, 23-32. [CrossRef] [PubMed]

34. van Keulen, L.J.M.; Bossers, A.; Van Zijderveld, F.G. TSE pathogenesis in cattle and sheep. Vet. Res. 2008, $39,24$. [CrossRef]

35. Sigurdson, C.J.; Williams, E.S.; Miller, M.W.; Spraker, T.R.; O’Rourke, K.I.; Hoover, E.A. Oral transmission and early lymphoid tropism of chronic wasting disease $\mathrm{PrP}^{\mathrm{res}}$ in mule deer fawns (Odocoileus hemionus). J. Gen. Virol. 1999, 80, 2757-2764. [CrossRef]

36. Glaysher, B.R.; Mabbott, N.A. Role of the draining lymph node in scrapie agent transmission from the skin. Immunol. Lett. 2007, 109, 64-71. [CrossRef]

37. Prinz, M.; Huber, G.; Macpherson, A.J.S.; Heppner, F.L.; Glatzel, M.; Eugster, H.-P.; Wagner, N.; Aguzzi, A. Oral prion infection requires normal numbers of Peyer's patches but not of enteric lymphocytes. Am. J. Pathol. 2003, 162, 1103-1111. [CrossRef]

38. Horiuchi, M.; Furuoka, H.; Kitamura, N.; Shinagawa, M. Alymphoplasia mice are resistant to prion infection via oral route. Jpn. J. Vet. Res. 2006, 53, 149-157.

39. Glaysher, B.R.; Mabbott, N.A. Role of the GALT in scrapie agent neuroinvasion from the intestine. J. Immunol. 2007, 178, 3757-3766. [CrossRef] 
40. Donaldson, D.S.; Else, K.J.; Mabbott, N.A. The gut-associated lymphoid tissues in the small intestine, not the large intestine, play a major role in oral prion disease pathogenesis. J. Virol. 2015, 15, 9532-9547. [CrossRef]

41. Mabbott, N.A.; MacPherson, G.G. Prions and their lethal journey to the brain. Nat. Rev. Microbiol. 2006, 4, 201-211. [CrossRef] [PubMed]

42. Aguzzi, A.; Heikenwalder, M. Pathogenesis of prion diseases: Current status and future outlook. Nat. Rev. Microbiol. 2006, 2006, 765-775. [CrossRef] [PubMed]

43. Mabbott, N.A. Prion pathogenesis and secodary lymphoid organs (SLO): Tracking the SLO spread of prions to the brain. Prion 2012, 6, 322-333. [CrossRef] [PubMed]

44. Aguzzi, A.; Nuvolone, M.; Zhu, C. The immunobiology of prion diseases. Nat. Rev. Immunol. 2013, 13, 888-902. [CrossRef]

45. Mabbott, N.A.; Alibhai, J.D.; Manson, J.C. The role of the immune system in prion infection. In Human Prion Diseases; Pocchiari, M., Manson, J., Eds.; Elsevier BV: San Diego, CA, USA, 2018; pp. 85-110. [CrossRef]

46. Marsh, R.F. Effect of Vaccina-activated macrophages on scrapie infection in hamsters. In Hamster Immune Responses in Infectious and Oncologic Diseases. Advances in Experimental Medicine and Biology; Wayne Streilein, J., Hart, D.A., Stein-Streilein, J., Duncan, W.R., Billingham, R.E., Eds.; Springer: Boston, MA, USA, 1981; Volume 134, pp. 359-363.

47. Outram, G.W.; Dickinson, A.G.; Fraser, H. Reduced Susceptibility to Scrapie In Mice After Steroid Administration. Nature 1974, 249, 855-856. [CrossRef]

48. Sethi, S.; Lipford, G.; Wagner, H.; Kretzschmar, H. Postexposure prophylaxis against prion disease with a stimulator of innate immunity. Lancet 2002, 360, 229-230. [CrossRef]

49. Heikenwalder, M.; Polymenidou, M.; Junt, T.; Sigurdson, C.; Wagner, H.; Akira, S.; Zinkernagel, R.; Aguzzi, A. Lymphoid follicle destruction and immunosuppression after repeated $\mathrm{CpG}$ oligodeoxynucleotide administration. Nat. Med. 2004, 10, 187-192. [CrossRef]

50. Apanius, V.; Penn, D.; Slev, P.R.; Ruff, L.R.; Potts, W.K. The nature of selection on the major histocompatibility complex. Crit. Rev. Immunol. 1997, 17, 179-224. [CrossRef]

51. Jackson, G.S.; Beck, J.A.; Navarrete, C.; Brown, J.; Sutton, P.M.; Contreras, M.; Collinge, J. HLA-DQ7 antigen and resistance to variant CJD. Nature 2001, 414, 269-270. [CrossRef]

52. Pepys, M.B.; Bybee, A.; Booth, D.R.; Bishop, M.T.; Will, R.G.; Little, A.-M.; Prokupek, B.; Madrigal, J.A. MHC typing in variant Creutzfeldt-Jakob disease. Lancet 2003, 361, 487-489. [CrossRef]

53. Lewicki,H.; Tishon, A.; Homann, D.; Mazarguil,H.; Laval, F.; Asensio, V.C.; Campbell, I.L.; DeArmond, S.; Coon, B.; Teng, C.; et al. T cells infiltrate the brain in murine and human transmissible spongiform encephalopathies. J. Virol. 2003, 77, 3799-3808. [CrossRef] [PubMed]

54. Kujala, P.; Raymond, C.; Romeijn, M.; Godsave, S.F.; van Kasteren, S.I.; Wille, H.; Prusiner, S.B.; Mabbott, N.A.; Peters, P.J. Prion uptake in the gut: Identification of the first uptake and replication sites. PLoS Pathog. 2011, 7, e1002449. [CrossRef] [PubMed]

55. Fraser, H.; Brown, K. Peripheral Pathogenesis of Scrapie in Normal and Immunocompromised Mice. Anim. Technol. 1994, 45, 21-22.

56. Brown, K.L.; Stewart, K.; Ritchie, D.; Mabbott, N.A.; Williams, A.; Fraser, H.; Morrison, W.I.; Bruce, M.E. Scrapie replication in lymphoid tissues depends on PrP-expressing follicular dendritic cells. Nat. Med. 1999, 5, 1308-1312. [CrossRef] [PubMed]

57. McCulloch, L.; Brown, K.L.; Bradford, B.M.; Hopkins, J.; Bailey, M.; Rajewsky, K.; Manson, J.C.; Mabbott, N.A. Follicular dendritic cell-specific prion protein $(\mathrm{PrPC})$ expression alone is sufficient to sustain prion infection in the spleen. PLoS Pathog. 2011, 7, e1002402. [CrossRef] [PubMed]

58. Beringue, V.; Herzog, L.; Jaumain, E.; Reine, F.; Sibille, P.; Le Dur, A.; Vilotte, J.-L.; Laude, H. Facilitated cross-species transmission of prions in extraneural tissue. Science 2012, 335, 472-475. [CrossRef] [PubMed]

59. Brown, K.L.; Mabbott, N.A. Evidence of subclinical prion disease in aged mice following exposure to bovine spongiform encephalopathy. J. Gen. Virol. 2014, 95, 231-243. [CrossRef]

60. Beringue, V.; Tixador, P.; Andreoletti, O.; Reine, F.; Castille, J.; Laï, T.-L.; Le Dur, A.; Laisne, A.; Herzog, L.; Passet, B.; et al. Host prion protein expression levels impact prion tropism for the spleen. PLoS Pathog. 2020, 16, e1008283. [CrossRef] 
61. Mabbott, N.A.; Young, J.; McConnell, I.; Bruce, M.E. Follicular dendritic cell dedifferentiation by treatment with an inhibitor of the lymphotoxin pathway dramatically reduces scrapie susceptibility. J. Virol. 2003, 77,6845-6854. [CrossRef]

62. Victoratos, P.; Lagnel, J.; Tzima, S.; Alimzhanov, M.B.; Rajewsky, K.; Pasparakis, M.; Kollias, G. FDC-specific functions of p55TNFR and IKK2 in the development of FDC networks and of antibody responses. Immunity 2006, 24, 65-77. [CrossRef]

63. Aguzzi, A.; Kranich, J.; Krautler, N.J. Follicular dendritic cells: Origin, phenotype, and function in health and disease. Trends Immunol. 2014, 35, 105-113. [CrossRef] [PubMed]

64. Heesters, B.A.; Myers, R.C.; Carroll, M.C. Follicular dendritic cells: Dynamic antigen libraries. Nat. Rev. Immunol. 2014, 14, 495-504. [CrossRef] [PubMed]

65. Mabbott, N.A.; Bruce, M.E.; Botto, M.; Walport, M.J.; Pepys, M.B. Temporary depletion of complement component C3 or genetic deficiency of C1q significantly delays onset of scrapie. Nat. Med. 2001, 7, 485-487. [CrossRef] [PubMed]

66. Klein, M.A.; Kaeser, P.S.; Schwarz, P.; Weyd, H.; Xenarios, I.; Zinkernagel, R.M.; Carroll, M.C.; Verbeek, J.S.; Botto, M.; Walport, M.J.; et al. Complement facilitates early prion pathogenesis. Nat. Med. 2001, 7, 488-492. [CrossRef]

67. Zabel, M.D.; Heikenwalder, M.; Prinz, M.; Arright, I.; Schwarz, P.; Kranich, J.; Von Teichman, A.; Haas, K.M.; Zeller, N.; Tedder, T.F.; et al. Stromal complement receptor CD21/35 facilitates lymphoid prion colonization and pathogenesis. J. Immunol. 2007, 179, 6144-6152. [CrossRef]

68. Kane, S.J.; Farley, T.K.; Gordon, E.O.; Estep, J.; Bender, H.R.; Moreno, J.A.; Bartz, J.; Telling, G.C.; Pickering, M.C.; Zabel, M.D. Complement regulatory protein factor $\mathrm{H}$ is a soluble prion receptor that potentiates peripheral prion pathogenesis. J. Immunol. 2017, 199, 3821-3827. [CrossRef]

69. Kane, S.J.; Swanson, E.; Gordon, E.O.; Rocha, S.; Bender, H.R.; Donius, L.R.; Hannan, J.P.; Zabel, M.D. Relative impact of complement receptors CD21/35 (Cr2/1) on scrapie pathogenesis in mice. mSphere 2017, 2, e00493-17. [CrossRef]

70. Michel, B.; Ferguson, A.; Johnson, T.; Bender, H.; Meyerett-Reid, C.; Pulford, B.; von Teichman, A.; Seelig, D.; Weiss, J.H.; Telling, G.C.; et al. Genetic depletion of complement receptors CD21/35 prevents terminal prion disease in a mouse model of chronic wasting disease. J. Immunol. 2012, 189, 4520-4527. [CrossRef]

71. Michel, B.; Ferguson, A.; Johnson, T.; Bender, H.; Meyerett-Reid, C.; Wycoff, A.C.; Pulford, B.; Telling, G.C.; Zabel, M.D. Complement protein $\mathrm{C} 3$ exacerbates prion disease in a mouse model of chronic wasting disease. Int. Immunol. 2013, 25, 697-702. [CrossRef]

72. Mabbott, N.A.; Mackay, F.; Minns, F.; Bruce, M.E. Temporary inactivation of follicular dendritic cells delays neuroinvasion of scrapie. Nat. Med. 2000, 6, 719-720. [CrossRef]

73. Mabbott, N.A.; McGovern, G.; Jeffrey, M.; Bruce, M.E. Temporary blockade of the tumour necrosis factor signaling pathway impedes the spread of scrapie to the brain. J. Virol. 2002, 76, 5131-5139. [CrossRef] [PubMed]

74. Mohan, J.; Bruce, M.E.; Mabbott, N.A. Follicular dendritic cell dedifferentiation reduces scrapie susceptibility following inoculation via the skin. Immunology 2005, 114, 225-234. [CrossRef] [PubMed]

75. Montrasio, F.; Frigg, R.; Glatzel, M.; Klein, M.A.; Mackay, F.; Aguzzi, A.; Weissmann, C. Impaired prion replication in spleens of mice lacking functional follicular dendritic cells. Science 2000, 288, 1257-1259. [CrossRef]

76. Bremer, J.; Heikenwalder, M.; Haybaeck, J.; Tiberi, C.; Krautler, N.J.; Kurrer, M.O.; Aguzzi, A. Repetitive immunization enhances the susceptibility of mice to peripherally administered prions. PLoS ONE 2009, 4, e7160. [CrossRef] [PubMed]

77. Monflacone, A.P.; Szakal, A.K.; Tew, J.G. Increased leukocyte diversity and responsiveness to B-cell and T-cell mitogens in cell suspensiions prepared by enzymatically dissociating murine lymph nodes. J. Leukoc. Biol. 1986, 39, 617-628. [CrossRef] [PubMed]

78. Brown, K.L.; Wathne, G.J.; Sales, J.; Bruce, M.E.; Mabbott, N.A. The effects of host age on follicular dendritic cell status dramatically impair scrapie agent neuroinvasion in aged mice. J. Immunol. 2009, 183, 5199-5207. [CrossRef]

79. Avrahami, D.; Gabizon, R. Age-related alterations affect the susceptibility of mice to prion infection. Neurobiol. Aging 2011, 32, 2006-2015. [CrossRef] [PubMed] 
80. Brown, K.L.; Gossner, A.; Mok, S.; Mabbott, N.A. The effects of host age on the transport of complement-bound complexes to the spleen and the pathogenesis of intravenous scrapie infection. J. Virol. 2012, 86, 1228-1237. [CrossRef]

81. Turner, V.M.; Mabbott, N.A. Structural and functional changes to lymph nodes in ageing mice. Immunology 2017, 151, 239-247. [CrossRef]

82. Turner, V.M.; Mabbott, N.A. Ageing adversely affects the migration and function of marginal zone B cells. Immunology 2017, 151, 349-362. [CrossRef]

83. Diack, A.B.; Head, M.W.; McCutcheon, S.; Boyle, A.; Knight, R.; Ironside, J.W.; Manson, J.C.; Will, R.G. Variant CJD. 18 years of research and surveillance. Prion 2014, 2014, 286-295. [CrossRef] [PubMed]

84. St. Rose, S.; Hunter, N.; Matthews, D.; Foster, J.; Chase-Topping, M.E.; Kruuk, L.E.B.; Shaw, D.J.; Rhind, S.M.; Will, R.G.; Woolhouse, M.E.J. Comparative evidence for a link between Peyer's patch development and susceptibility to transmissible spongiform encephalopathies. Bmc Infect. Dis. 2006, 6, 5. [CrossRef] [PubMed]

85. Manson, J.C.; Clarke, A.R.; McBride, P.A.; McConnell, I.; Hope, J. PrP gene dosage determines the timing but not the final intensity or distribution of lesions in scrapie pathology. Neurodegeneration 1994, 3, 331-340.

86. Klein, M.A.; Frigg, R.; Raeber, A.J.; Flechsig, E.; Hegyi, I.; Zinkernagel, R.M.; Weissmann, C.; Aguzzi, A. PrP expression in B lymphocytes is not required for prion neuroinvasion. Nat. Med. 1998, 4, 1429-1433. [CrossRef] [PubMed]

87. Ierna, M.I.; Farquhar, C.F.; Outram, G.W.; Bruce, M.E. Resistance of neonatal mice to scrapie is associated with inefficient infection of the immature spleen. J. Virol. 2006, 80, 474-482. [CrossRef] [PubMed]

88. Lötscher, M.; Recher, M.; Hunzinker, L.; Klein, M.A. Immunologically induced, complement-dependent up-regulation of the prion protein in the mouse spleen: Follicular dendritic cells versus capsule and trabeculae. J. Immunol. 2003, 170, 6040-6047.

89. Glatzel, M.; Heppner, F.L.; Albers, K.M.; Aguzzi, A. Sympathetic innervation of lymphoreticular organs is rate limiting for prion neuroinvasion. Neuron 2001, 31, 25-34. [CrossRef]

90. McBride, P.A.; Schulz-Shaeffer, W.J.; Donaldson, M.; Bruce, M.; Diringer, H.; Kretzschmar, H.A.; Beekes, M. Early spread of scrapie from the gastrointestinal tract to the central nervous system involves autonomic fibers of the splanchnic and vagus nerves. J. Virol. 2001, 75, 9320-9327. [CrossRef]

91. Prinz, M.; Heikenwalder, M.; Junt, T.; Schwarz, P.; Glatzel, M.; Heppner, F.L.; Fu, Y.-X.; Lipp, M.; Aguzzi, A. Positioning of follicular dendritic cells within the spleen controls prion neuroinvasion. Nature 2003, 425, 957-962. [CrossRef]

92. Mabbott, N.A.; Donaldson, D.S.; Ohno, H.; Williams, I.R.; Mahajan, A. Microfold (M) cells: Important immunosurveillance posts in the intestinal epithelium. Mucosal Immunol. 2013, 6, 666-677. [CrossRef]

93. Rios, D.; Wood, M.B.; Li, J.; Chassaing, B.; Gewirtz, A.T.; Williams, I.R. Antigen sampling by intestinal M cells is the principal pathway initiating mucosal IgA production to commensal enteric bacteria. Mucosal Immunol. 2016, 9, 907-916. [CrossRef] [PubMed]

94. Takakura, I.; Miyazawa, K.; Kanaya, T.; Itani, W.; Watanabe, K.; Ohwada, S.; Watanabe, H.; Hondo, T.; Rose, M.T.; Mori, T.; et al. Orally administered prion protein is incorporated by $\mathrm{M}$ cells and spreads to lymphoid tissues with macrophages in prion protein knockout mice. Am. J. Pathol. 2011, 179, 1301-1309. [CrossRef] [PubMed]

95. Donaldson, D.S.; Kobayashi, A.; Ohno, H.; Yagita, H.; Williams, I.R.; Mabbott, N.A. M cell depletion blocks oral prion disease pathogenesis. Mucosal Immunol. 2012, 5, 216-225. [CrossRef] [PubMed]

96. Donaldson, D.S.; Sehgal, A.; Rios, D.; Williams, I.R.; Mabbott, N.A. Increased abundance of M cells in the gut epithelium dramatically enhances oral prion disease susceptibility. PLoS Pathog. 2016, 12, e1006075. [CrossRef]

97. Tahoun, A.; Mahajan, S.; Paxton, E.; Malterer, G.; Donaldson, D.S.; Wang, D.; Tan, A.; Gillespie, T.L.; O'Shea, M.; Rose, A.; et al. Salmonella transforms follicle-associated epithelial cells into M cells to promote intestinal invasion. Cell Host Microbe 2012, 12, 645-666. [CrossRef]

98. Donaldson, D.S.; Pollock, J.; Vohra, P.; Stevens, M.P.; Mabbott, N.A. Microbial stimulation reverses the age-related decline in $\mathrm{M}$ cells in aged mice. iScience 2020, 23, 101147. [CrossRef]

99. Knoop, K.A.; Kumar, N.; Butler, B.R.; Sakthivel, S.K.; Taylor, R.T.; Nochi, T.; Akiba, H.; Yagita, H.; Kiyono, H.; Williams, I.R. RANKL is necessary and sufficient to initiate development of antigen-sampling $M$ cells in the intestinal epithelium. J. Immunol. 2009, 183, 5738-5747. [CrossRef] 
100. Nakato, G.; Fukuda, S.; Hase, K.; Goitsuka, R.; Cooper, M.D.; Ohno, H. New approach for M-cell-specific molecules by screening comprehensive transcriptome analysis. Dna Res. 2009, 16, 227-235. [CrossRef]

101. Sigurdson, C.J.; Heikenwalder, M.; Manco, G.; Barthel, M.; Schwarz, P.; Stecher, B.; Krautler, N.J.; Hardt, W.-D.; Seifert, B.; MacPherson, A.J.S.; et al. Bacterial colitis increases susceptibility to oral prion pathogenesis. J. Infect. Dis. 2009, 199, 243-252. [CrossRef]

102. Marshall, A.; Bradford, B.M.; Clarke, A.R.; Manson, J.C.; Mabbott, N.A. Oral prion neuroinvasion occurs independently of $\mathrm{PrP}^{\mathrm{C}}$ expression in the gut epithelium. J. Virol. 2018. [CrossRef]

103. Kobayashi, A.; Donaldson, D.S.; Erridge, C.; Kanaya, T.; Williams, I.R.; Ohno, H.; Mahajan, A.; Mabbott, N.A. The functional maturation of $\mathrm{M}$ cells is dramatically reduced in the Peyer's patches of aged mice. Mucosal Immunol. 2013, 6, 1027-1037. [CrossRef] [PubMed]

104. Bennet, K.M.; Parnell, E.A.; Sanscartier, C.; Parks, S.; Chen, G.; Nair, M.G.; Lo, D.D. Induction of colonic M cells during intestinal inflammation. Am. J. Pathol. 2016, 186, 166-179. [CrossRef] [PubMed]

105. Wood, M.B.; Rios, D.; Williams, I.R. TNF-a augments RANKL-dependent intestinal M-cell differentiation in enteroid cultures. Am. J. Physiol. Cell Physiol. 2016, 311, C498-C507. [CrossRef] [PubMed]

106. Krautler, N.J.; Kana, V.; Kranich, J.; Tian, Y.; Perera, D.; Lemm, D.; Schwarz, P.; Armulik, A.; Browning, J.L.; Tallquist, M.; et al. Follicular dendritic cells emerge from ubiquitous perivascular precursors. Cell 2012, 150, 194-206. [CrossRef] [PubMed]

107. Wykes, M.; Pombo, A.; Jenkins, C.; MacPherson, G.G. Dendritic cells interact directly with Naive B lymphocytes to transfer antigen and initiate class switching in a primary T-dependent response. J. Immunol. 1998, 161, 1313-1319. [PubMed]

108. Raymond, C.R.; Aucouturier, P.; Mabbott, N.A. In vivo depletion of CD11c ${ }^{+}$cells impairs scrapie agent neuroinvasion from the intestine. J. Immunol. 2007, 179, 7758-7766. [CrossRef] [PubMed]

109. Cordier-Dirikoc, S.; Chabry, J. Temporary depletion of CD11c+ dendritic cells delays lymphoinvasion after intraperitoneal scrapie infection. J. Virol. 2008, 82, 8933-8936. [CrossRef]

110. Wathne, G.J.; Kissenpfennig, A.; Malissen, B.; Zurzolo, C.; Mabbott, N.A. Determining the role of mononuclear phagocytes in prion neuroinvasion from the skin. J. Leukoc. Biol. 2012, 91, 817-828. [CrossRef]

111. Bradford, B.M.; Reizis, B.; Mabbott, N.A. Oral prion disease pathogenesis is impeded in the specific absence of CXCR5-expressing dendritic cells. J. Virol. 2017, 91, e00124-17. [CrossRef]

112. Bradford, B.M.; Sester, D.; Hume, D.A.; Mabbott, N.A. Defining the anatomical localisation of subsets of the murine mononuclear phagocyte system using integrin alpha X (Itgax, CD11c) and colony stimulating factor 1 receptor (Csf1r, CD115) expression fails to discriminate dendritic cells from macrophages. Immunobiology 2011, 216, 1228-1237. [CrossRef]

113. Bonnardel, J.; Da Silva, C.; Henri, S.; Tamoutounour, S.; Chasson, L.; Mantanana-Sanchis, F.; Gorvel, J.P.; Lelouard, H. Innate and adaptive immune functions of Peyer's patch-derived monocyte-derived cells. Cell Rep. 2015, 11, 770-784. [CrossRef] [PubMed]

114. Bonnardel, J.; Da Silva, C.; Wagner, C.; Bonifay, R.; Chasson, L.; Masse, M.; Pollet, E.; Dalod, M.; Gorvel, J.-P.; Lelouard, H. Distribution, location, and transcriptional profile of Peyer's patch conventional DC subsets at steady state and under TLR7 ligand stimulation. Mucosal Immunol. 2017, 10, 1412-1430. [CrossRef] [PubMed]

115. Sethi, S.; Kerksiek, K.M.; Brocker, T.; Kretzschmar, H. Role of the CD8 ${ }^{+}$dendritic cell subset in transmission of prions. J. Virol. 2007, 81, 4877-4880. [CrossRef] [PubMed]

116. Oldstone, M.B.A.; Race, R.; Thomas, D.; Lewicki, H.; Homman, D.; Smelt, S.; Holz, A.; Koni, P.; Lo, D.; Chesebro, B.; et al. Lymphotoxin-a- and lymphotoxin-b-deficient mice differ in susceptibility to scrapie: Evidence against dendritic cell involvement. J. Virol. 2002, 76, 4357-4363. [CrossRef]

117. Ano, Y.; Sakudo, A.; Nakayama, H.; Onodera, T. Uptake and dynamics of infectious prion protein in the intestine. Prot. Pept. Lett. 2009, 16, 247-255. [CrossRef]

118. Carp, R.I.; Callahan, S.M. In vitro interaction of scrapie agent and mouse peritoneal macrophages. Intervirology 1981, 16, 8-13. [CrossRef]

119. Carp, R.I.; Callahan, S.M. Effect of mouse peritoneal macrophages on scrapie infectivity during extended in vitro incubation. Intervirology 1982, 17, 201-207. [CrossRef]

120. Beringue, V.; Demoy, M.; Lasmezas, C.I.; Gouritin, B.; Weingarten, C.; Deslys, J.-P.; Andreux, J.P.; Couvreur, P.; Dormont, D. Role of spleen macrophages in the clearance of scrapie agent early in pathogenesis. J. Pathol. 2000, 190, 495-502. [CrossRef] 
121. Maignien, T.; Shakweh, M.; Calvo, P.; Marce, D.; Sales, N.; Fattal, E.; Deslys, J.-P.; Couvreur, P.; Lasmezas, C.I. Role of gut macrophages in mice orally contaminated with scrapie or BSE. Int. J. Pharm. 2005, 298, 293-304. [CrossRef]

122. Sehgal, A.; Donaldson, D.S.; Pridans, C.; Sauter, K.A.; Hume, D.A.; Mabbott, N.A. The role of CSF1R-dependent macriophages in control of the intestinal stem-cell niche. Nat. Commun. 2018, 9, 1272. [CrossRef]

123. Gabanyi, I.; Muller, P.A.; Feighery, L.; Oliveira, T.Y.; Costa-Pinto, F.A.; Mucida, D. Neuro-immune interactions drive tissue programming in intestinal macrophages. Cell 2016, 164, 378-391. [CrossRef] [PubMed]

124. Muller, P.A.; Koscso, B.; Rajani, G.M.; Stevanovic, K.; Berres, M.-L.; Hashimoto, D.; Mortha, A.; Leboeuf, M.; Li, X.-M.; Mucida, D.; et al. Crosstalk between muscularis macrophages and enteric neurones regulates gastrointestinal motility. Cell 2014, 158, 300-313. [CrossRef] [PubMed]

125. Courth, L.F.; Ostaff, M.J.; Mailander-Sanchez, D.; Malek, N.P.; Stange, E.F.; Wehkamp, J. Crohn's disease-derived monocytes fail to induce Paneth cell defensins. Proc. Natl. Acad. Sci. USA 2015, 112, 14000-14005. [CrossRef] [PubMed]

126. Nusse, Y.M.; Savage, A.K.; Marangoni, P.; Rosendahl-Huber, A.K.M.; Landman, T.A.; de Sauvage, F.J.; Locksley, R.M.; Klein, O.D. Parasitic helminths induce fetal-like reversion in the intestinal stem cell niche. Nature 2018, 559, 109-113. [CrossRef] [PubMed]

127. Seeger, H.; Heikenwalder, M.; Zeller, N.; Kranich, J.; Schwarz, P.; Gaspert, A.; Seifert, B.; Miele, G.; Aguzzi, A. Coincident scrapie infection and nephritis lead to urinary prion excretion. Science 2005, 310, 324-326. [CrossRef]

128. Ligios, C.; Cancedda, G.M.; Margalith, I.; Santucciu, C.; Madau, L.; Maestrale, C.; Basagni, M.; Saba, M.; Heikenwalder, M. Intraepithelial and interstitial deposition of pathological prion protein in kidneys of scrapie-affected sheep. PLoS ONE 2007, 2, e859. [CrossRef]

129. Ligios, C.; Sigurdson, C.; Santucciu, C.; Carcassola, G.; Manco, G.; Basagni, M.; Maestrale, C.; Cancedda, M.G.; Madau, L.; Aguzzi, A. PrPSc in mammary glands of sheep affected by scrapie and mastitis. Nat. Med. 2005, 11, 1137-1138. [CrossRef]

130. Lacroux, C.; Simon, S.; Benenstad, S.L.; Maillet, S.; Mathey, J.; Lugan, S.; Corbiere, F.; Cassard, H.; Costes, P.; Bergonier, D.; et al. Prions in milk from ewes incubating natural scrapie. PLoS Pathog. 2008, 4, e1000238. [CrossRef]

131. Ligios, C.; Cancedda, M.G.; Carta, A.; Santucciu, C.; Maestrale, C.; Demontis, F.; Saba, M.; Patta, C.; DeMartini, J.C.; Aguzzi, A.; et al. Sheep with scrapie and mastitis transmit infectious prions through the milk. J. Virol. 2011, 85, 1136-1139. [CrossRef]

132. Heikenwalder, M.; Kurrer, M.O.; Margalith, I.; Kranich, J.; Zeller, N.; Haybaeck, J.; Polymenidou, M.; Matter, M.; Bremer, J.; Jackson, W.S.; et al. Lymphotoxin-dependent prion replication in inflammatory stromal cells of granulomas. Immunity 2008, 29, 998-1008. [CrossRef]

133. Al-Dybiat, I.; Moudjou, M.; Martin, D.; Reine, F.; Herzog, L.; Truchet, S.; Berthon, P.; Laude, H.; Rezaei, H.; Andreoletti, O.; et al. Prion strain-dependent tropism is maintained between spleen and granuloma and relies on lymphoreticular structures. Sci. Rep. 2019, 9, 14656. [CrossRef] [PubMed]

134. Sánchez-Quintero, A.; Bradford, B.M.; Maizels, R.; Donaldson, D.S.; Mabbott, N.A. Effect of co-infection with a small intestine-restricted helminth pathogen on oral prion disease pathogenesis in mice. Sci. Rep. 2019, 9, 6674. [CrossRef] [PubMed]

135. Gruner, L.; Elsen, J.M.; Vu Tien Khang, J.; Eychenne, F.; Caritez, J.C.; Jacquiet, P.; Andreoletti, O.; Sarradin, P.; Cortet, J.; Richer, N.; et al. Nematode parasites and scrapie: Experiments in sheep and mice. Parasitol. Res. 2004, 93, 493-498. [CrossRef] [PubMed]

136. Donaldson, D.S.; Bradford, B.M.; Artis, D.; Mabbott, N.A. Reciprocal development of lymphoid tissue development in the large intestine by IL-25 and IL-23. Mucosal Immunol. 2015, 8, 582-595. [CrossRef]

137. Gonzalez, L.; Martin, S.; Siso, S.; Konold, T.; Ortiz-Pelaez, A.; Phelan, L.; Goldmann, W.; Stewart, P.; Saunders, G.; Windl, O.; et al. High prevalence of scrapie in a dairy goat herd: Tissue distribution of disease-associated PrP and effect of PRNP genotype and age. Vet. Res. 2009, 40, 65. [CrossRef]

138. Thomsen, B.V.; Schneider, D.A.; O’Rourke, K.I.; Gidlewski, T.; McLane, J.; Allen, R.W.; mcIsaac, A.A.; Mitchell, G.B.; Keane, D.P.; Spraker, T.R.; et al. Diagnostic accuracy of rectal mucosa biopsy testing for chronic wasting disease within white-tailed deer (Odocoileus virginianus) herds in North America: Effects of age, sex, polymorphism at PRNP codon 96, and disease progression. J. Vet. Diagn. Intest. 2012, 24, 878-887. [CrossRef] 
139. Kimura, S.; Yamakami-Kimura, M.; Obata, Y.; Hase, K.; Kitamura, H.; Ohno, H.; Iwanaga, T. Visualization of the entire differentiation process of murine M cells: Suppression of their maturation in caecal patches. Mucosal Immunol. 2015, 8, 650-660. [CrossRef]

140. Pelaseyed, T.; Bergstrom, J.H.; Gustafsson, J.K.; Emund, A.; Birchenough, G.M.H.; Schutte, A.; van der Post, S.; Svensson, F.; Rodriguez-Pineiro, A.M.; Nystrom, E.E.L.; et al. The mucus and mucins of the goblet cells and enterocytes provide the first defense line of the gastrointestinal tract and interact with the immune system. Immunol. Rev. 2014, 260, 8-20. [CrossRef]

141. Lai, N.Y.; Musser, M.A.; Pinho-Ribeiro, F.A.; Baral, P.; Jacobson, A.; Potts, D.E.; Chen, Z.; Paik, D.; Soualhi, S.; Yan, Y.; et al. Gut-innervating nociceptor neurons regulate Peyer's patch microfold cells and SFB levels to mediate Salmonella host defense. Cell 2020, 180, 33-39. [CrossRef]

142. Woolf, C.J.; Ma, Q. Nociceptors-Noxious stimulus detectors. Neuron 2007, 55, 353-364. [CrossRef]

143. Sandberg, M.K.; Al-Doujaily, H.; Shaps, A.R.; Clarke, A.R.; Collinge, J. Prion propagation and toxicity in vivo occur in two distinct mechanistic phases. Nature 2011, 470, 540-542. [CrossRef] [PubMed]

144. Betmouni, S.; Perry, V.H.; Gordon, J.L. Evidence for an early inflammatory response in the centralnervous-system of mice with scrapie. Neuroscience 1996, 74, 1-5. [CrossRef]

145. Friedman-Levi, Y.; Ovadia, H.; Hoftberger, R.; Einstein, O.; Abramsky, O.; Budka, H.; Gabizon, R. Fatal neurological disease in scrapie-infected mice induced for experimental autoimmune encephalomyelitis. J. Virol. 2007, 81, 9942-9949. [CrossRef] [PubMed]

146. Vincenti, J.E.; Murphy, L.; Grabert, K.; McColl, B.W.; Cancellotti, E.; Freeman, T.C.; Manson, J.C. Defining the microglial response during the time course of chronic neurodegeneration. J. Virol. 2016, 90, 3003-3017. [CrossRef]

147. Alibhai, J.; Blanco, R.A.; Barria, M.A.; Piccardo, P.; Caughey, B.; Perry, V.H.; Freeman, T.C.; Manson, J.C. Distribution of misfolded prion protein seeding activity alone does not predict regions of neurodegeneration. Plos Biol. 2016, 14, e1002579. [CrossRef]

148. Sorce, S.; Nuvulone, M.; Russo, G.; Chincisan, A.; Heinzer, D.; Avar, M.; Pfammatter, M.; Schwarz, P.; Delic, M.; Muller, M.; et al. Genome-wide transcriptomics identifies an early preclinical signature of prion infection. PLoS Pathog. 2020, 16, e1008653. [CrossRef]

149. Alliot, F.; Godin, I.; Pessac, B. Microglia derive from progenitors, originating from the yolk sac, and which proliferate in the brain. Dev. Brain. Res. 1999, 117, 145-152. [CrossRef]

150. Askew, K.; Li, K.; Olmos-Alonso, A.; Garcia-Moreno, F.; Liang, Y.; Richardson, P.; Tipton, T.; Chapman, M.A.; Riecken, K.; Beccari, S.; et al. Coupled proliferation and apoptosis maintain the rapid turnover of microglia in the adult brain. Cell Rep. 2017, 18, 391-405. [CrossRef]

151. Gomez-Nicola, D.; Schetters, S.T.T.; Perry, V.H. Differential role of CCR2 in the dynamics of microglia and perivascular macrophages during prion disease. Glia 2014, 62, 1041-1052. [CrossRef]

152. Gomez-Nicola, D.; Fransen, N.L.; Suzzi, S.; Perry, V.H. Regulation of microglial proliferation during chronic neurodegeneration. J. Neurosci. 2013, 33, 2481-2493. [CrossRef]

153. Bruce, M.E.; McBride, P.A.; Farquhar, C.F. Precise targeting of the pathology of the sialoglycoprotein, $\operatorname{PrP}$, and vacuolar degeneration in mouse scrapie. Neurosci. Lett. 1989, 102, 1-6. [CrossRef]

154. Priller, J.; Prinz, M.; Heikenwalder, M.; Zeller, N.; Schwarz, P.; Heppner, F.L.; Aguzzi, A. Early and rapid engraftment of bone marrow-derived microglia in scrapie. J. Neurosci. 2006, 26, 11753-11762. [CrossRef] [PubMed]

155. Montrasio, F.; Cozzio, A.; Flechsig, E.; Rossi, D.; Klein, M.A.; Rulicke, T.; Raeber, A.J.; Vosshenrich, C.A.J.; Proft, J.; Aguzzi, A.; et al. B-lymphocyte-restricted expression of the prion protein does not enable prion replication in PrP knockout mice. Proc. Natl. Acad. Sci. USA 2001, 98, 4034-4037. [CrossRef] [PubMed]

156. Raeber, A.J.; Sailer, A.; Hegyi, I.; Klein, M.A.; Rulicke, T.; Fischer, M.; Brandner, S.; Aguzzi, A.; Weissmann, C. Ectopic expression of prion protein (PrP) in T lymphocytes or hepatocytes of PrP knockout mice is insufficient to sustain prion replication. Proc. Natl. Acad. Sci. USA 1999, 96, 3987-3992. [CrossRef] [PubMed]

157. Hume, D.A.; Caruso, M.; Ferrari-Cestari, M.; Summers, K.M.; Pridans, C.; Irvine, K.M. Phenotypic impacts of CSF1R deficiencies in humans and model organisms. J. Leukoc. Biol. 2020, 107, 205-219. [CrossRef]

158. Wang, Y.; Szretter, K.J.; Vermi, W.; Gilfillan, S.; Rossini, C.; Cella, M.; Barrow, A.D.; Diamond, M.S.; Colonna, M. IL-34 is a tissue-restricted ligand of CSF1R required for the development of Langerhans cells and microglia. Nat. Immunol. 2012, 13, 753-760. [CrossRef] 
159. Zhu, C.; Hermann, U.S.; Falsig, J.; Abakumova, I.; Nuvolone, M.; Schwarz, P.; Frauenknecht, K.; Rushing, E.J.; Aguzzi, A. A neuroprotective role for microglia during prion diseaes. J. Exp. Med. 2016, 213, 1047-1059. [CrossRef]

160. Carroll, J.A.; Race, B.; Williams, K.; Striebel, J.; Chesebro, B. Microglia are critical in host defence against prion disease. J. Virol. 2018, 92. [CrossRef]

161. Lei, F.; Cui, N.; Zhou, C.; Chodosh, J.; Vavvas, D.G.; Paschalis, E.I. CSF1R inhibition by a small-molecule inhibitor is not microglia specific; affecting hematopoiesis and the function of macrophages. Proc. Natl. Acad. Sci. USA 2020, in press. [CrossRef]

162. Kranich, J.; Krautler, N.J.; Falsig, J.; Ballmer, B.; Li, S.; Hutter, G.; Schwarz, P.; Moos, R.; Julius, C.; Miele, G.; et al. Engulfment of cerebral apoptotic bodies controls the course of prion disease in a mouse strain-dependent manner. J. Exp. Med. 2010, 207, 2271-2281. [CrossRef]

163. Zhu, C.; Herrmann, U.S.; Li, B.; Abakumova, I.; Moos, R.; Schwarz, P.; Rushing, E.J.; Colonna, M.; Aguzzi, A. Triggering receptor expressed on myeloid cells- 2 is involved in prion-induced microglial activation but does not contribute to prion pathogenesis in mouse brains. Neurobiol. Aging 2015, 36, 1994-2002. [CrossRef] [PubMed]

164. Zhang, H.; Li, F.; Yang, Y.; Chen, J.; Hu, X. SIRP/CD47 signaling in neurological disorders. Brain Res. 2015, 1623, 74-80. [CrossRef] [PubMed]

165. Nuvulone, M.; Paolucci, M.; Sorce, S.; Kana, V.; Moos, R.; Matozaki, T.; Aguzzi, A. Prion pathogenesis is unaltered in the absence of SIRPa-mediated "dont-eat-me" signaling. PLoS ONE 2017, 12, e0177876. [CrossRef]

166. Crocker, P.R.; Kelm, S.; Dubois, C.; Martin, B.; McWilliam, A.S.; Shotton, D.M.; Paulson, J.C.; Gordon, S. Purification and properties of sialoadhesin, a sialic acid-binding receptor of murine tissue macrophages. Embo J. 1991, 10, 1661-1669. [CrossRef] [PubMed]

167. Bogie, J.F.; Boelen, E.; Louagie, E.; Delputte, P.; Elewaut, D.; van Horssen, J.; Hendricks, J.J.; Hellings, N. CD169 is a marker for highly pathogenic phagocytes in multiple sclerosis. Mult. Scler. 2018, 24, 290-300. [CrossRef] [PubMed]

168. Makarava, N.; Chang, J.C.-Y.; Baskakov, I.V. Region-specific sialylation pattern of prion strains provides novel insight into prion neurotropism. Int. J. Mol. Sci. 2020, 21, 828. [CrossRef] [PubMed]

169. Bradford, B.M.; Crocker, P.R.; Mabbott, N.A. Peripheral prion disease pathogenesis is unaltered in the absence of sialoadhesin (Siglec-1/CD169). Immunology 2014, 143, 120-129. [CrossRef] [PubMed]

170. Cunningham, C.; Wilcockson, D.C.; Boche, D.; Perry, V.H. Comparison of inflammatory and acute-phase responses in the brain and peripheral organs of the ME7 model of prion disease. J. Virol. 2005, 79, 5174-5184. [CrossRef]

171. Fadok, V.A.; Bratton, D.L.; Konowal, A.; Freed, P.W.; Westcott, J.Y.; Henson, P.M. Macrophages that have ingested apoptotic cells in vitro inhibit proinflammatory cytokine production through autocrine/paracrine mechanisms involving TGF-beta, PGE2, and PAF. J. Clin. Investig. 1998, 101, 890-898. [CrossRef]

172. Nuvolone, M.; Sorce, S.; Schwarz, P.; Aguzzi, A. Prion pathogenesis in the absence of NLRP3/ASC inflammasomes. PLoS ONE 2015, 10, e0117208. [CrossRef]

173. Julius, C.; Heikenwalder, M.; Schwarz, P.; Marcel, A.; Karin, M.; Prinz, M.; Pasparakis, M.; Aguzzi, A. Prion propagation in mice lacking central nervous system NF-kappaB signalling. J. Gen. Virol. 2008, 89, 1545-1550. [CrossRef] [PubMed]

174. Prinz, M.; Heikenwalder, M.; Scwarz, P.; Takeda, K.; Akira, S.; Aguzzi, A. Prion pathogenesis in the absence of Toll-like receptor signalling. Embo Rep. 2003, 4, 195-199. [CrossRef] [PubMed]

175. Guijarro, I.M.; Garcés, M.; Andrés-Benito, P.; Marín, B.; Otero, A.; Barrio, T.; Carmona, M.; Ferrer, I.; Badiola, J.J.; Monzón, M. Assessment of glial activation response in the progress of natural scrapie after chronic dexamethesone treatment. Int. J. Mol. Sci. 2020, 21, 3231. [CrossRef] [PubMed]

176. Cunningham, C.; Boche, D.; Perry, V.H. Transforming growth factor b1, the dominant cytokine in murine prion disease: Influence on inflammatory cytokine synthesis and alteration of vascular extracellular matrix. Neuropathol. Appl. Neurobiol. 2002, 28, 107-119. [CrossRef] [PubMed]

177. Carroll, J.A.; Race, B.; Williams, K.; Striebel, J.; Chesebro, B. RNA-seq and network analysis reveal unique glial gene expression signatures during prion infection. Mol. Brain 2020, 13, 71. [CrossRef] 
178. De Lucia, C.; Rinchon, A.; Olmos-Alsonso, A.; Riecken, K.; Fehse, B.; Boche, D.; Perry, V.H.; Gomez-Nicola, D. Microglia regulate hippocampal neurogenesis during chronic neurodegeneration. BrainBehav. Immun. 2016, 55, 179-190. [CrossRef]

179. Boche, D.; Cunningham, C.; Gauldie, J.; Perry, V.H. Transforming growth factor-beta 1-mediated neuroprotection against excitotoxic injury in vivo. J. Cereb. Blood Flow Metab. 2003, 23, 1174-1182. [CrossRef]

180. Srivastava, S.; Katorcha, E.; Makarava, N.; Barrett, J.P.; Loane, D.J.; Baskakov, I.V. Inflammatory response of microglia to prions is controlled by sialylation of PrPSc. Sci. Rep. 2018, 8, 11326. [CrossRef]

181. Perry, V.H.; Newma, T.A.; Cunningham, C. The impact of systemic infection on the progression of neurodegenerative disease. Nat. Rev. Neurosci. 2003, 4, 103-112. [CrossRef]

182. Cunningham, C.; Wilcockson, D.C.; Campion, S.; Lunnon, K.; Perry, V.H. Central and systemic endotoxin challenges exacerbate the local inflammatory response and increase neuronal death during chronic neurodegeneration. J. Neurosci. 2005, 25, 9275-9284. [CrossRef]

183. Cunningham, C.; Campion, S.; Lunnon, K.; Murray, C.L.; Woods, J.F.C.; Deacon, R.M.J.; Rawlins, J.N.P.; Perry, V.H. Systemic inflammation induces acute behavioural and cognitive changes and accelerates neurodegenerative disease. Biol. Psychiatry 2009, 65, 304-312. [CrossRef] [PubMed]

184. Lunnon, K.; Teeling, J.L.; Tutt, A.L.; Cragg, M.S.; Glennie, M.J.; Perry, V.H. Systemic inflammation modulates Fc receptor expression on microglia during chronic neurodegeneration. J. Immunol. 2011, 186, 7215-7224. [CrossRef] [PubMed]

185. Nakagaki, T.; Ishibashi, D.; Mori, T.; Miyazaki, Y.; Takatsuki, H.; Tange, H.; Tagauchi, Y.; Satoh, K.; Atarashi, R.; Nishida, N. Administration of FK506 from late stage of disease prolongs survival of human prion-inoculated mice. Neurotherapeutics 2020, in press. [CrossRef] [PubMed]

186. Russell, W.R.; Hoyles, L.; Flint, H.J.; Dumas, M.E. Colonic bacterial metabolites and human health. Curr. Opin. Microbiol. 2013, 16, 246-254. [CrossRef]

187. Kamada, N.; Kim, Y.G.; Sham, H.P.; Vallance, B.A.; Puente, J.L.; Martens, E.C.; Nunez, G. Regulated virulence controls the ability of a pathogen to compete with the gut microbiota. Science 2012, 336, 1325-1329. [CrossRef]

188. Furusawa, Y.; Obata, Y.; Fukuda, S.; Endo, T.A.; Nakato, G.; Takahashi, D.; Nakanishi, Y.; Uetake, c.; Kato, K.; Kato, T; et al. Commensal microbe-derived butyrate induces the differentiation of colonic regulatory T cells. Nature 2013, 504, 446-450. [CrossRef]

189. Hooper, L.V.; Littman, D.R.; Macpherson, A.J. Interactions between the microbiota and the immune system. Science 2012, 336, 1268-1273. [CrossRef]

190. Erny, D.; Hrabě de Angelis, A.L.; Prinz, M. Communicating systems in the body: How microbiota and microglia cooperate. Immunology 2017, 150, 7-15. [CrossRef]

191. Ceppa, F.A.; Izzo, L.; Sardelli, L.; Raimondi, I.; Tunesi, M.; Albani, D.; Giordano, C. Human gut-microbiota interaction in neurodegenerative disorders and current engineered tools for its modeling. Front. Cell. Infect. Microbiol. 2020, 10, 296. [CrossRef]

192. Erny, D.; Hrabe de Angelis, A.L.; Jaitin, D.; Wieghofer, P.; Staszewski, O.; David, E.; Keren-Shaul, H.; Mahlakoiv, T.; Jakobshagen, K.; Buch, T.; et al. Host microbiota constantly control maturation and function of microglia in the CNS. Nat. Neurosci. 2015, 18, 965-977. [CrossRef]

193. Fang, P.; Kazmi, S.A.; Jameson, K.G.; Hsiao, E.Y. The microbiome as a modifier of neurodegenerative disease risk. Cell Host Microbe 2020, 28, 201-222. [CrossRef] [PubMed]

194. Miyauchi, E.; Kim, S.-W.; Suda, W.; Kawasumi, M.; Onawa, S.; Taguchi-Atarashi, N.; Morita, H.; Taylor, T.D.; Hattori, M.; Ohno, H. Gut microorganisms act together to exacerbate inflammation in spinal cords. Nature 2020, in press. [CrossRef] [PubMed]

195. Bradford, B.M.; Tetlow, L.; Mabbott, N.A. Prion disease pathogenesis in the absence of the commensal microbiota. J. Gen. Virol. 2017, 98, 1943-1952. [CrossRef] [PubMed]

196. Donaldson, D.S.; Mabbott, N.A. The influence of the commensal and pathogenic gut microbiota on prion disease pathogenesis. J. Gen. Virol. 2016, 97, 1725-1738. [CrossRef]

197. De Luigi, A.; Colombo, L.; Diomede, L.; Capobianco, R.; Mangieri, M.; Miccolo, C.; Limido, L.; Forloni, G.; Tagliavini, F.; Salmona, M. The efficacy of tetracyclines in peripheral and intracerebral prion infection. PLoS ONE 2008, 3, e1888. [CrossRef]

198. Sun, J.; Shigemi, H.; Tanaka, Y.; Yamauchi, T.; Ueda, T.; Iwasaki, H. Tetracyclines downregulate the production of LPS-induced cytokines and chemokines in THP-1 cells via ERK, p38, and nuclear factor kB signaling pathways. Biochem. Biophys. Rep. 2015, 4, 397-404. [CrossRef] 
199. Tagliavini, F.; Forloni, G.; Colombo, L.; Rossi, G.; Girola, L.; Canciani, B.; Angretti, N.; Giampaolo, L.; Pressini, E.; Awan, T.; et al. Tetracycline affects abnormal properties of synthetic PrP peptides and $\mathrm{PrPSc}^{\mathrm{Sc}}$ in vitro. J. Mol. Biol. 2000, 300, 1309-1322. [CrossRef]

200. Allen, N.J.; Bennett, M.L.; Foo, L.C.; Wang, G.X.; Chakroborty, C.; Smith, S.J.; Barres, B.A. Astrocyte glypicans 4 and 6 promote formation of excitatory synapses via GluA1 AMPA receptors. Nature 2012, 486, 410-414. [CrossRef]

201. Kucukdereli, H.; Allen, N.J.; Lee, A.T.; Feng, A.; Ozlu, M.I.; Conaster, L.M.; Chakroborty, C.; Workman, G.; Weaver, M.; Sage, E.H.; et al. Control of excitatory CNS synaptogenesis by astrocyte-secreted proteins Hevin and SPARC. Proc. Natl. Acad. Sci. USA 2011, 108, E440-E449. [CrossRef]

202. Chung, W.-S.; Clarke, L.E.; Wang, G.X.; Stafford, B.K.; Sher, A.; Chakroborty, C.; Joung, J.; Foo, L.C.; Thompson, A.; Chen, C.; et al. Astrocytes mediate synapse elimination through MEGF10 and MERTK pathways. Nature 2013, 504, 394-400. [CrossRef]

203. Smith, H.L.; Freeman, O.J.; Butcher, A.J.; Holmqvist, S.; Humoud, I.; Schatzl, T.; Hughes, D.T.; Verity, N.C.; Swinden, D.P.; Hayes, J.; et al. Astrocyte unfolded protein response induces a specific reactivity state that causes non-cell-autonomous neuronal degeneration. Neuron 2020, 105, 1-12. [CrossRef] [PubMed]

204. Sofroniew, M.V. Astrocyte reactivity: Subtypes, states, and functions in CNS innate immunity. Trends Immunol. 2020, in press. [CrossRef] [PubMed]

205. Damisah, E.C.; Hill, R.A.; Rai, A.; Chen, F.; Rothlin, C.V.; Ghosh, S.; Grutzendler, J. Astrocytes and microglia play orchestrated roles and respect phagocytic territories during neuronal corpse removal in vivo. Sci. Adv. 2020, 6, eaba3239. [CrossRef] [PubMed]

206. Raeber, A.J.; Race, R.E.; Brandner, S.; Priola, S.A.; Sailer, A.; Bessen, R.A.; Mucke, L.; Manson, J.; Aguzzi, A.; Oldstone, B.A.; et al. Astrocyte-specific expression of hamster prion protein (PrP) renders PrP knockout mice susceptible to hamster scrapie. Embo J. 1997, 16, 6057-6065. [CrossRef]

207. Moreno, J.A.; Radford, H.; Peretti, D.; Steinert, J.R.; Verity, N.; Martin, M.G.; Halliday, M.; Morgan, J.; Dinsdale, D.; Ortori, C.A.; et al. Sustained translational repression by eIF2aP mediates prion neurodegeneration. Nature 2012, 485, 507-511. [CrossRef]

208. Kitchen, P.; Salman, M.M.; Halsey, A.M.; Clarke-Bland, C.; MacDonald, J.A.; Ishida, H.; Vogel, H.J.; Almuturi, S.; Logan, A.; Kreida, S.; et al. Targeting aquaporin-4 subcellular localization to treat central nervous system edema. Cell 2020, 181, 7799-7894. [CrossRef]

209. Liddelow, S.A.; Marsh, S.E.; Stevens, B. Microglia and astrocytes in disease: Dynamic duo or partners in crime? Trends Immunol. 2020, in press. [CrossRef]

210. Bohlen, C.J.; Bennett, F.C.; Tucker, A.F.; Collins, H.Y.; Mulinyawe, S.B.; Barres, B.A. Diverse requirements for microglial survival, specification and funciton revealed by defined-medium cultures. Neuron 2017, 94, 759-773. [CrossRef]

211. Liddelow, S.A.; Guttenplan, K.A.; Clarke, L.E.; Bennet, F.L.; Bohlen, C.J.; Schirmer, L.; Bennet, M.L.; Munch, A.E.; Chung, W.-S.; Peterson, T.C.; et al. Neurotoxic reactive astrocytes are induced by activated microglia. Nature 2017, 541, 481-487. [CrossRef]

212. Guttenplan, K.A.; Stafford, B.K.; El-Danaf, R.; Adler, D.I.; Munch, A.E.; Weigel, M.K.; Huberman, A.D.; Liddelow, S.A. Neurotoxic reactive astrocytes drive neuronal death after retinal injury. Cell Rep. 2020, 31, 107776. [CrossRef]

213. Donaldson, D.S.; Bradford, B.M.; Else, K.J.; Mabbott, N.A. Accelerated onset of CNS prion disease in mice co-infected with a gastrointestinal helminth pathogen during the preclincal phase. Sci. Rep. 2020, 10, 4554. [CrossRef] [PubMed]

214. Hartmann, K.; Sepulveda-Falla, D.; Rose, I.V.L.; Madore, C.; Muth, C.; Matschke, J.; Butovsky, O.; Liddelow, S.A.; Glatzel, M.; Krasemann, S. Complement 3+-astrocytes are highly abundant in prion diseases, but their abolishment led to an accelerated disease course and early dysregulation of microglia. Acta Neuropath. Commun. 2020, 7, 83. [CrossRef] [PubMed]

215. Bradford, B.M.; Wijaya, C.A.W.; Mabbott, N.A. Discrimination of prion strain targeting in the central nervous system via reactive astrocyte heterogeneity in CD44 expression. Front. Cell. Neurosci. 2019, 13, 411. [CrossRef] [PubMed]

216. Mabbott, N.A.; Williams, A.; Farquhar, C.F.; Pasparakis, M.; Kollias, G.; Bruce, M.E. Tumor necrosis factor-alpha-deficient, but not interleukin-6-deficient, mice resist peripheral infection with scrapie. J. Virol. 2000, 74, 3338-3344. [CrossRef] [PubMed] 
217. Prinz, M.; Montrasio, F.; Klein, M.A.; Schwarz, P.; Priller, J.; Odermatt, B.; Pfeffer, K.; Aguzzi, A. Lymph nodal prion replication and neuroinvasion in mice devoid of follicular dendritic cells. Proc. Natl. Acad. Sci. USA 2002, 99, 919-924. [CrossRef]

218. Rojo, R.; Raper, A.; Ozdemir, D.D.; Lefevre, L.; Grabert, K.; Wollscheid-Lengeling, E.; Bradford, B.; Caruso, M.; Gazova, I.; Sanchez, A.; et al. Deletion of a Csf1r enhancer selectively impacts CSF1R expression and development of tissue macrophage populations. Nat. Commun. 2019, 10, 3215. [CrossRef]

219. Hennessy, E.; Griffin, E.W.; Cunningham, C. Astrocytes are primed by chronic neurodegeneration to produce exaggerated chemokine and cell infiltration responses to acute stimulation with the cytokines IL-1b and TNF-a. J. Neurosci. 2015, 35, 8411-8422. [CrossRef]

220. Wheeler, M.A.; Clark, I.C.; Tjon, E.C.; Li, Z.; Zandee, S.E.J.; Couturier, C.P.; Watson, B.R.; Scalisis, G.; Alkwai, S.; Rothhammer, V.; et al. MAFG-driven astrocytes promote CNS inflammation. Nature 2020, 578, 593-599. [CrossRef]

221. Ehresmann, D.W.; Hogan, R.N. Acceleration of scrapie disease in mice by an adenovirus. Intervirology 1986, 25, 103-110. [CrossRef]

222. Lins, N.; Mourao, L.; Trévia, N.; Passos, A.; Farias, J.A.; Assunção, J.; Quintairos, A.; Bento-Torres, J.; Sosthene, M.C.K.; Diniz, J.A.P.; et al. Virus infections on prion diseased mice exacerbate inflammatory microglial response. Oxidative Med. Cell. Longev. 2016, 2016, 3974648. [CrossRef]

223. Muth, C.; Schrock, K.; Madore, C.; Hartmann, K.; Fanek, Z.; Butovsky, O.; Glatzel, M.; Krasemann, S. Activation of microglia by retroviral infection correlates with transient clearance of prions from the brain but does not change incubation time. Brain Pathol. 2017, 27, 590-602. [CrossRef] [PubMed]

224. Krasemann, S.; Neumann, M.; Luepke, J.-P.; Grashorn, J.; Wurr, S.; Stocking, C.; Glatzel, M. Persistent retroviral infection with MoMuLV influences neuropathological signature and phenotype of prion disease. Acta Neuropathol. 2012, 124, 111-126. [CrossRef] [PubMed]

225. Bancroft, A.J.; Else, K.J.; Grencis, R.K. Low-level infection with Trichuris muris significantly affects the polarization of the CD4 response. Eur. J. Immunol. 1994, 24, 3113-3118. [CrossRef] [PubMed]

226. Else, K.J.; Finkelman, F.D.; Maliszewski, C.R.; Grencis, R.K. Cytokine-mediated regulation of chronic intestinal helminth infection. J. Exp. Med. 1994, 179, 347-351. [CrossRef]

227. Hashioka, S.; Klegeris, A.; Schwab, S.; McGeer, P.L. Interferon-g-dependent cytotoxic activation of human astrocytes and astrocytoma cells. Neurobiol. Aging 2009, 30, 1924-1935. [CrossRef]

228. Walsh, D.T.; Betmouni, S.; Perry, V.H. Absence of detectable IL-1 beta production in murine prion disease: A model of chronic neurodegeneration. J. Neuropathol. Exp. Neurol. 2001, 60, 173-182. [CrossRef]

229. Halonen, S.K.; Woods, T.A.; McInnerney, K.; Weiss, L.M. Microarray analysis of IFN-gamma response genes in astrocytes. J. Neuroimmunol. 2006, 175, 19-30. [CrossRef]

230. Lundh, M.; Bugliani, M.; Dahlby, T.; Chou, D.H.C.; Wagner, B.; Ghiasi, S.M.; De Tata, V.; Chen, Z.; Lund, M.N.; Davies, M.J.; et al. The immunoproteasome is induced by cytokines and regulates apoptosis in human islets. J. Endocrinol. 2017, 233, 369-379. [CrossRef]

231. McFarlin, D.E.; Raff, M.C.; Simpson, E.; Nehlsen, S.H. Scrapie in immunologically deficient mice. Nature 1971, 233, 336. [CrossRef]

232. Bonney, S.; Seitz, S.; Ryan, C.A.; Jones, K.L.; Clarke, P.; Tyler, K.L.; Siegenthaler, J.A. Gamma interferon alters junctional integrity via Rho kinase resulting in blood-brain barrier leakage in experimental viral encephalitis. mBio 2019, 10, e01675-19. [CrossRef]

233. Gate, D.; Saligrama, N.; Leventhal, O.; Yang, A.C.; Unger, M.S.; Middeldorp, J.; Chen, K.; Lehallier, B.; Channappa, D.; De Los Santos, M.B.; et al. Clonally-expanded CD8 T cells patrol the cerebrospinal fluid in Alzheimer's disease. Nature 2020, 577, 399-404. [CrossRef]

234. Owens, T.; Khorooshi, R.; Wlodarczyk, A.; Asgari, N. Interferons in the central nervous system: A few instruments play many tunes. Glia 2014, 62, 339-355. [CrossRef] [PubMed]

235. Nazmi, A.; Field, R.H.; Griffin, E.W.; Haugh, O.; Hennessy, E.; Cox, D.; Reis, R.; Tortorelli, L.; Murray, C.L.; Lopez-Rodriguea, A.B.; et al. Chronic neurodegeneration induces type I interferon systhesis via STING, shaping microglial phenotype and accelerating disease progression. Glia 2019, 67, 1254-1276. [CrossRef] [PubMed]

236. Keating, S.E.; Baran, M.; Bowie, A.G. Cytosolic DNA sensors regulating type I interferon induction. Trends Immunol. 2011, 32, 574-581. [CrossRef] [PubMed] 
237. Baker, C.A.; Lu, Z.Y.; Manuelidis, L. Early induction of interferon-responsive mRNAs in Creutzfeldt-Jakob disease. J. Neurovirology 2004, 10, 29-40. [CrossRef] [PubMed]

238. Field, R.; Campion, S.; Warren, C.; Murray, C.; Cunningham, C. Systemic challenge with the TLR3 agonist poly I:C induces amplified IFNa/b and IL- $1 \mathrm{~b}$ responses in the disease brain and exacerbates chronic neurodegeneration. Brain Behav. Immun. 2010, 24, 996-1007. [CrossRef]

239. Ishibashi, D.; Atarashi, R.; Fuse, T.; Nagaki, T.; Yamaguchi, N.; Satoh, K.; Honda, K.; Nishida, N. Protective role of interferon regulatory factor 3-mediated signaling against prion infection. J. Virol. 2012, in press. [CrossRef]

240. Ishibashi, D.; Homma, T.; Nakagaki, T.; Fuse, T.; Sano, K.; Sato, K.; Mori, T.; Atarashi, R.; Nishida, N. Type I interferon protects neurons from prions in in vivo models. Brain 2019, 142, 1035-1050. [CrossRef]

241. Wu, F.; Zhao, S.; Yu, B.; Chen, Y.-M.; Wang, W.; Song, Z.-S.; Hu, Y.; Tao, Z.-W.; Pei, Y.-Y.; Yuan, M.-L.; et al. A new coronavirus associated with human respiratory disease in China. Nature 2020, 579, 265-269. [CrossRef]

242. WHO. COVID-19 situation reports; WHO: Geneva, Switzerland, 2020; Volume 2020.

243. England, N. COVID-19 Daily Deaths. Available online: https://web.archive.org/web/20200501094237 (accessed on 25 August 2020).

244. Atkins, J.L.; Masoli, J.A.H.; Delgado, J.; Pilling, L.C.; Kuo, C.L.; Kuchel, G.A.; Melzer, D. Preexisting comorbidities predicting COVID-19 and mortality in the UK biobank community cohort. J. Gerontol. 2020, in press. [CrossRef]

245. Williamson, E.J.; Walker, A.J.; Bhaskaran, K.; Bacon, S.; Bates, C.; Morton, C.E.; Curtis, H.J.; Mehrkar, A.; Evans, D.; Inglesby, P.; et al. Factors associated with COVID-19-related death using OpenSAFELY. Nature 2020, 584, 430-436. [CrossRef] [PubMed]

246. Holmes, C.; Cunningham, C.; Zotova, E.; Woolford, J.; Dean, C.; Kerr, S.; Culliford, D.; Perry, V.H. Systemic inflammation and disease progression in Alzheimer disease. Neurology 2009, 73, 768-774. [CrossRef] [PubMed]

247. Combrinck, M.I.; Perry, V.H.; Cunningham, C. Peripheral infection evokes exaggerated sickness behaviour in pre-clinical murine prion disease. Neuroscience 2002, 112, 7-11. [CrossRef]

248. Nerius, M.; Doblhammer, G.; Tamguney, G. GI infections are associated with an increased risk of Parkinson's disease. Gut 2020, 69, 1154-1156. [CrossRef]

249. Burberry, A.; Wells, M.F.; Limone, F.; Couto, A.; Smith, K.S.; Keaney, J.; Gillet, G.; van Gastel, N.; Wang, J.-Y.; Pietilainen, O.; et al. C9orf72 suppresses sytemic and neural inflammation induced by gut bacteria. Nature 2020, 582, 89-94. [CrossRef]

250. Young, M.J.; O’Hare, M.; Matiello, M.; Schmahmann, J.D. Creutzfeldt-Jakob disease in a man with COVID-19: SARS-CoV-2-accelerated neurodegeneration? Brain Behav. Immun. 2020, in press. [CrossRef]

251. Lucas, C.; Wong, P.; Klein, J.; Castro, T.B.R.; Silva, J.; Sundaram, M.; Ellingson, M.K.; Mao, T.; Oh, J.E.; Israelow, B.; et al. Longitudual analyses reveal immunological misfiring in severe COVID-19. Nature 2020, in press. [CrossRef]

252. Hennessy, E.; Gormley, S.; Lopez-Rodriguez, A.B.; Murray, C.; Murray, C.; Cunningham, C. Systemic TNF-a produces acute cognitive dysfunction and exagerated sickness behavior when superimposed upon progressive neurodegeneration. Brain Behav. Immun. 2017, 59, 233-244. [CrossRef]

253. Huang, C.; Wang, Y.; Li, X.; Ren, L.; Zhao, J.; Hu, Y.; Zhang, L.; Fan, G.; Xu, J.; Gu, X.; et al. Clinical features of patients infected with 2019 novel coronavirus in Wuhan, China. Lancet 2020, 395, 497-506. [CrossRef]

254. Payan-Gomez, C.; Rodriguez, D.; Amador-Munoz, D.; Ramirez-Clavijo, S. Integrative analysis of global gene expression identifies opposite patterns of reactive astrogliosis in aged human prefrontal cortex. Brain Sci. 2018, 8, 27. [CrossRef]

255. Bishop, M.T.; Hart, P.; Aitchison, L.; Baybutt, H.N.; Plinston, C.; Thomson, V.; Tuzi, N.L.; Head, M.W.; Ironside, J.W.; Will, R.G.; et al. Predicting susceptibility and incubation time of human-to-human transmission of vCJD. Lancet Neurol. 2006, 5, 393-398. [CrossRef]

256. Mabbott, N.A. Prospects for safe and effective vaccines against prion diseases. Expert Rev. Vaccines 2015, 14, 1-4. [CrossRef] [PubMed]

257. Frontzek, K.; Aguzzi, A. Recent developments in antibody therapeutics against prion disease. Emerg. Top. Life Sci. 2020, in press. [CrossRef]

258. Heppner, F.L.; Musahl, C.; Arrighi, I.; Klein, M.A.; Rulicke, T.; Oesch, B.; Zinkernagel, R.M.; Kalinke, U.; Aguzzi, A. Prevention of scrapie pathogenesis by transgenic expression of anti-prion protein antibodies. Science 2001, 294, 178-182. [CrossRef] 
259. White, A.R.; Enever, P.; Tayebi, M.; Mushens, R.; Lineham, J.; Brandner, S.; Anstee, D.; Collinge, J.; Hawke, S. Monoclonal antibodies inhibit prion replication and delay the development of prion disease. Nature 2003, 422, 80-83. [CrossRef]

260. University College London Hospitals. Sixth UCLH Patient to Recieve Innovative Drug for CJD. UCL News, 9 October 2019.

261. Neves, V.; Aires-da-Silva, F.; Corte-Real, S.; Castanho, M.A.R.B. Antibody approaches to treat brain diseases. Trends Biotechnol. 2015, 34, 36-48. [CrossRef]

262. Pain, C.; Dumont, J.; Dumoulin, M. Camelid single-domain antibody fragments: Uses and prospectives to investigate protein misfolding and aggregation, and to treat diseases associated with these phenomena. Biochimie 2015, 111, 82-106. [CrossRef]

263. Sonati, T.; Reimann, R.R.; Falsig, J.; Baral, P.K.; O'Connor, T.; Hornemann, S.; Yaganoglu, S.; Li, B.; Herrmann, U.S.; Wieland, B.; et al. The toxicity of antiprion antibodies is mediated by the flexible tail of the prion protein. Nature 2013, 501, 102-106. [CrossRef]

264. Reimann, R.R.; Sonati, T.; Hornemann, S.; Hermann, U.S.; Arand, M.; Hawke, S.; Aguzzi, A. Differential toxicity of antibodies to the prion protein. PLoS Pathog. 2016, 12, e1005401. [CrossRef]

265. Goñi, F.; Knudsen, E.; Schreiber, F.; Scholtzova, H.; Pankiewicz, J.; Carp, R.; Meeker, H.C.; Rubenstein, R.; Brown, D.R.; Sy, M.S.; et al. Mucosal vaccination delays or prevents prion infection via the oral route. Neuroscience 2005, 133, 413-421. [CrossRef]

266. Goñi, F.; Mathiason, C.K.; Yim, L.; Wong, K.; Hayes-Klug, J.; Nalls, A.; Peyser, D.; Estevez, V.; Denkers, N.; $\mathrm{Xu}, \mathrm{J} . ;$ et al. Mucosal immunization with an attenuated Salmonella vaccine partially protects white-tailed deer from chronic wasting disease. Vaccine 2015, 33, 726-733. [CrossRef] [PubMed]

267. Yoshida, M.; Claypool, S.M.; Wagner, J.S.; Mizoguchi, E.; Mizoguchi, A.; Roopenian, D.C.; Lencer, W.I.; Blumberg, R.S. Human neonatal Fc receptor mediates transport of IgG into luminal secretions for delivery of antigens to mucosal dendritic cells. Immunity 2004, 20, 769-783. [CrossRef] [PubMed]

268. Ano, Y.; Sakudo, A.; Uraki, R.; Sato, Y.; Kono, J.; Sugiura, K.; Yokoyama, T.; Itohara, S.; Nakayama, H.; Yukawa, M.; et al. Enhanced enteric invasion of scrapie agents into the villous columnar epithelium via maternal immunoglobulin. Int. J. Mol. Med. 2010, 26, 845-851. [CrossRef]

269. Frontzek, K.; Carta, M.; Losa, M.; Epskamp, M.; Meisl, G.; Anane, A.; Brandel, J.-P.; Camenisch, U.; Castilla, J.; Haik, S.; et al. Autoantibodies against the prion protein in individuals with PRNP mutations. Neurology 2020, in press. [CrossRef] [PubMed]

270. Senatore, A.; Frontzek, K.; Emmenegger, M.; Chincisan, A.; Losa, M.; Reimann, R.; Horny, G.; Guo, J.; Fels, S.; Sorce, S.; et al. Protective anti-prion antibodies in human immunoglobulin repertoires. Embo Mol. Med. 2020, e12739, in press. [CrossRef] 